\title{
PTEN, a Barrier for Proliferation and Metastasis of Gastric Cancer Cells: From Molecular Pathways to Targeting and Regulation
}

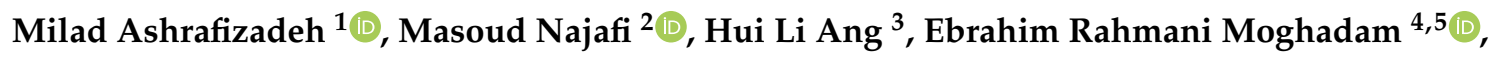 \\ Mahmood Khaksary Mahabady ${ }^{6}{ }^{(1)}$, Amirhossein Zabolian ${ }^{7}$, Leila Jafaripour ${ }^{8}$, \\ Atefe Kazemzade Bejandi ${ }^{7}$, Kiavash Hushmandi ${ }^{9}$, Hossein Saleki ${ }^{7}$, Ali Zarrabi ${ }^{10,11, *(1)}$ and \\ Alan Prem Kumar 3 **(D) \\ 1 Department of Basic Science, Faculty of Veterinary Medicine, University of Tabriz, Tabriz 5166616471, Iran; \\ dvm.milad73@yahoo.com \\ 2 Radiology and Nuclear Medicine Department, School of Paramedical Sciences, \\ Kermanshah University of Medical Sciences, Kermanshah 6715847141, Iran; najafi_ma@yahoo.com \\ 3 Cancer Science Institute of Singapore and Department of Pharmacology, Yong Loo Lin School of Medicine, \\ National University of Singapore, Singapore 119077, Singapore; e0336095@u.nus.edu \\ 4 Department of Anatomical Sciences, School of Medicine, Student Research Committee, \\ Shiraz University of Medical Sciences, Shiraz 7134814336, Iran; e_rahmani@sums.ac.ir \\ 5 Kazerun Health Technology Incubator, Shiraz University of Medical Sciences, Shiraz 6461665145, Iran \\ 6 Anatomical Sciences Research Center, Institute for Basic Sciences, Kashan University of Medical Sciences, \\ Kashan 8715988141, Iran; Khaksary-m@kaums.ac.ir \\ 7 Young Researchers and Elite Club, Tehran Medical Sciences, Islamic Azad University, \\ Tehran 1916893813, Iran; Fzr2000_0007@yahoo.com (A.Z.); Atefe.kazemzade@yahoo.com (A.K.B.); \\ hosseinsaleki2015@gmail.com (H.S.) \\ 8 Department of Anatomy, School of Medicine, Dezful University of Medical Sciences, \\ Dezful 3419759811, Iran; elahejafari62@gmail.com \\ 9 Department of Food Hygiene and Quality Control, Division of Epidemiology \& \\ Zoonoses, Faculty of Veterinary Medicine, University of Tehran, Tehran 1417414418, Iran; \\ houshmandi.kia7@ut.ac.ir \\ 10 Sabanci University Nanotechnology Research and Application Center (SUNUM), \\ Tuzla 34956, Istanbul, Turkey \\ 11 Center of Excellence for Functional Surfaces and Interfaces (EFSUN), Faculty of Engineering and Natural \\ Sciences, Sabanci University, Tuzla 34956, Istanbul, Turkey \\ * Correspondence: alizarrabi@sabanciuniv.edu (A.Z.); csiapk@nus.edu.sg (A.P.K.)
}

Received: 1 July 2020; Accepted: 23 July 2020; Published: 3 August 2020

\begin{abstract}
Cancer is one of the life-threatening disorders that, in spite of excellent advances in medicine and technology, there is no effective cure for. Surgery, chemotherapy, and radiotherapy are extensively applied in cancer therapy, but their efficacy in eradication of cancer cells, suppressing metastasis, and improving overall survival of patients is low. This is due to uncontrolled proliferation of cancer cells and their high migratory ability. Finding molecular pathways involved in malignant behavior of cancer cells can pave the road to effective cancer therapy. In the present review, we focus on phosphatase and tensin homolog (PTEN) signaling as a tumor-suppressor molecular pathway in gastric cancer (GC). PTEN inhibits the PI3K/Akt pathway from interfering with the migration and growth of GC cells. Its activation leads to better survival of patients with GC. Different upstream mediators of PTEN in GC have been identified that can regulate PTEN in suppressing growth and invasion of GC cells, such as microRNAs, long non-coding RNAs, and circular RNAs. It seems that antitumor agents enhance the expression of PTEN in overcoming GC. This review focuses on aforementioned topics to provide a new insight into involvement of PTEN and its downstream and upstream mediators in GC. This will direct further studies for evaluation of novel signaling networks and their targeting for suppressing GC progression.
\end{abstract}


Keywords: gastric cancer; phosphatase and tensin homolog (PTEN); PI3K/Akt; metastasis; growth

\section{Introduction}

Cancer is still a leading cause of death worldwide, and its epidemiology is changing based on alterations in risk factors, its classification, advances in therapy and detection, and finally, demographic changes, such as aging, immigration, and population growth [1]. Regardless of the incidence rate of cancer, treatment of cancer requires an integrated plan to reveal all dimensions of a certain cancer to know how each cancer cell is able to ensure its survival. In spite of progresses in different fields such as cancer immunotherapy, radiotherapy, and chemotherapy that have been beneficial in improving life quality and overall survival of patients with cancer, overcoming cancer needs more advancement. Two factors, namely uncontrolled growth and metastasis of cancer cells in malignant tumors, should be considered to provide effective treatment for patients [2-6]. In malignant tumor, strategies such as chemotherapy, radiotherapy, immunotherapy, and surgery are just able to improve overall survival of patients and cannot completely eradicate cancer cells. Thus, studies have been directed toward molecular targeting of cancer cells [7-11]. Consequently, identification of molecular profile of each cancer can provide a milestone progress in achieving an effective treatment [12-14]. Recently, we demonstrated how phosphatase and tensin homolog (PTEN) signaling can target bladder cancer cells and how they can be regulated by other molecular pathways [15]. Since PTEN is a well-known target in cancers, and a high number of studies have focused on revealing its role in different cancers, we decided to provide another review with a focus on gastric cancer (GC). In the present review, we focus on PTEN as an onco-suppressor signaling that undergoes downregulation in gastric cancer (GC) cells. Our aim is to reveal signaling networks involved in regulation of PTEN in GC and how PTEN activation can significantly improve survival of patients with GC. This review can provide a new insight toward targeting PTEN in future studies, using pharmacological or genetic interventions, to obtain a solution for GC treatment.

\section{PTEN Signaling: An Overview}

Since expression of PTEN undergoes downregulation in cancer cells, it has attracted much attention in the field of cancer therapy [16-23]. PTEN was first discovered in 1997 when mutations were investigated at 10q23 locus in chromosome 10, and it was found that PTEN is an onco-suppressor gene [24]. Structurally, PTEN gene has nine exons, and it encodes a 403-aminoacid protein that has both protein and lipid phosphatase roles $[25,26]$. PTEN has five functional domains $[27,28]$ : (1) an N-terminal phosphatidylinositol 4-5-diphosphate (PIP2)-binding domain, (2) a phosphatase domain, (3) a membrane-targeting C2 domain, (4) a C-terminal tail, and (5) a PDZ binding motif. Reduction in expression of PTEN can result in carcinogenesis, and uncontrolled proliferation and metastasis of cancer cells [29,30]. Increased malignancy of cancer cells after PTEN deletion is due to activation of the PI3K/Akt signaling pathway [31-33]. In fact, PTEN is an inhibitory of the aforementioned signaling network, and downregulation of PTEN leads to activation of the PI3K/Akt signaling pathway and increased proliferation of cancer cells [34-39]. Thus, before discussing the role of PTEN signaling in cancer malignancy, it would be beneficial to describe PTEN at the molecular level.

PTEN is involved in the stimulation of cell cycle arrest at G1 phase via inhibiting formation of PIP3 and reducing its level via conversing PIP3 to PIP2 [40]. PI3K induces PIP3 formation from PIP2 to activate the Akt signaling pathway. By suppressing PIP3 formation, PTEN exerts an inhibitory effect on the PI3K/Akt axis. The next step is the activation of mTOR signaling, which promotes both the migration and proliferation of cancer cells [41,42]. Thus, disrupting PI3K/Akt/mTOR signaling by PTEN leads to a dramatic decrease in survival and metastasis of cancer cells [43-45]. This is the pathway for lipid phosphatase activity of PTEN. In exerting protein phosphatase activity, PTEN dephosphorylates FAK and SHC proteins to negatively affect cell survival, proliferation, and invasion 
of cancer cells. Moreover, PTEN promotes chromosome stability by binding into TP53 in the nucleus. This interaction of PTEN with TP53 also mediates cell cycle arrest [46]. Figure 1 provides a schematic representation of PTEN signaling.

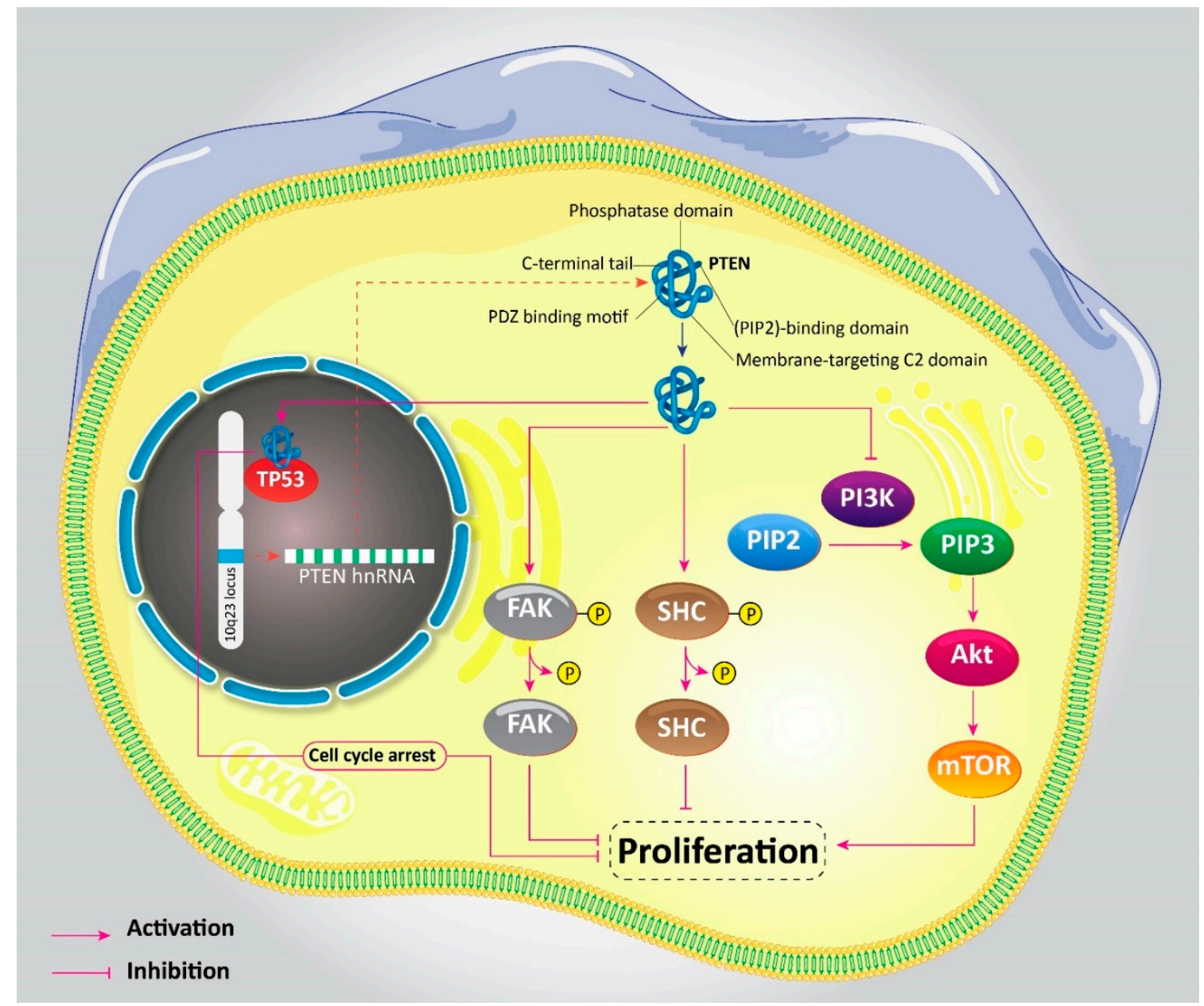

Figure 1. Phosphatase and tensin homolog (PTEN) signaling pathway and its interactions.

\section{PTEN Pathway in Oncology}

Inactivation of PTEN can occur at different levels, such as genetic mutation, transcriptional, and post-transcriptional levels [47]. Moreover, epigenetic mechanisms can inhibit PTEN expression via promoter hyper-methylation and histone acetylation. It is worth mentioning that activity and subcellular localization of PTEN can be affected by ubiquitination, phosphorylation, acetylation, oxidation, and sumoylation, leading to tumorigenesis [48-52]. Loss of PTEN expression is correlated with advanced tumor stage and resistance of cancer cells to chemotherapy [53]. In different cancers, such as breast, prostate, and endometrium cancers, PTEN can be considered as a prognostic and predictive biomarker for the response of cancer cells into chemotherapy [54]. The PTEN gene has a difference compared to classical onco-suppressor genes. Although classical onco-suppressor genes require complete silencing to stimulate carcinogenesis, a slight reduction in PTEN expression can lead to tumorigenesis [55]. The effect of partial loss of PTEN and its association with tumorigenesis have been investigated in hypomorphic mouse models [25,56,57]. PTEN activation can mediate resistance to ionizing radiation therapy. This is due to the significant role of PTEN in promoting chromatin stability and enhancing DNA repair, not the oncogene role of PTEN. After induction of DNA damage, phosphorylation of PTEN occurs at tyrosine240, and, in turn, PTEN attaches to chromatin. Then, it recruits RAD51 to enhance DNA repair [54]. Another study also demonstrates that exposing into 
radiation is correlated with the loss of heterozygosity of TP53 and PTEN and predisposing into tumorigenesis [58]. More studies are needed to clarify expression of PTEN during radiation therapy.

Thus, activation of PTEN can be considered as a promising strategy in cancer therapy. It seems that the downregulation of transient receptor potential vanilloid type 4 (TRPV4) provides condition for stimulation of PTEN and suppressing progression of colon cancer cells [59]. The loss of PTEN inhibits its interaction with NKX3.1 in the nucleus. As a consequence, NKX3.1 undergoes degradation, resulting in increased malignancy of cancer cells [60]. Different factors function as upstream mediators of PTEN in cancer cells. It seems that, in bladder cancer, PTEN is inhibited by nuclear factor-kappaB (NF-kB) signaling cascade, which can promote tumorigenesis [61-64]. USP13 suppresses NF-kB to promote PTEN expression, resulting in antitumor activity [65]. Long non-coding RNA (lncRNA) TUSC8 stimulates PTEN expression via miR-641 downregulation, to inhibit the progression of cervical cancer cells [66]. Thus, PTEN is a potential onco-suppressor factor, and its downregulation can facilitate progression of cancer cells [67].

\section{PTEN in Clinical Studies}

Clinical studies have also shown the onco-suppressor role of PTEN, and its downregulation in cancer cells. In an experiment conducted on men with prostate cancer, it was found that PTEN loss is associated with metastasis and invasion of cancer cells, and undesirable prognosis [68]. In another experiment in China, on breast cancer patients, occurrence of PTEN mutation is 4.8\% [69]. PTEN can be used as a biomarker for response of patients with cancer into chemotherapy. Moreover, PTEN loss is related to pathologic complete response (pCR) [70]. A study conducted on colorectal patients (198 patients from 2006 to 2008 that enrolled in Taipei Veterans General Hospital) extensively examined different aspects of the PTEN gene in these patients. Mutation in the PTEN gene and the inhibition of its protein expression, inducing promoter hypermethylation and reduced DNA copy number, occur in patients with colorectal cancer. This study revealed that loss of PTEN is more common in the advanced stage (stage IV, 56.9\% loss), compared to the initial stage (stage I, 20\% loss). However, it was shown that PTEN deactivation has no effect on prognosis [71]. Although this experiment showed PTEN is not correlated with prognosis of colorectal patients, another study demonstrates that PTEN can be considered as a reliable biomarker for prognosis of patients with head and neck cancer, so that PTEN loss shows poor survival and prognosis [72]. These studies demonstrate there is no certain role for PTEN in clinical studies. This story is more complicated by study of Stern and colleagues. They showed that PTEN loss occurs in patients with breast cancer, but it is not associated with chemoresistance [73]. Thus, more clinical studies are required to examine the special role of PTEN in cancer patients. It seems that PTEN has a different role in each cancer type, and this role can be more specified by considering the age, sex, and race of patients with cancer [74,75].

\section{PTEN and Gastric Cancer}

Epigenetic Regulation of PTEN.

\subsection{MicroRNAs Target PTEN}

Briefly, miRs belong to non-coding RNAs (ncRNAs) from the subcategory of regulatory RNAs [76-78]. Although miRs comprise a large section of genome and are not translated into proteins, they exert regulatory effects on important cellular events, such as proliferation, migration, and so on [79-86]. In terms of regulation of the PTEN signaling pathway, miRs have demonstrated great potential. Increasing evidence demonstrates that miRs are able to dually downregulate and upregulate PTEN in cancer cells [69,87-91]. In the following sections, we focus on the relationship between miRs and PTEN signaling in GC cells. 


\subsubsection{MicroRNAs and PTEN Induction}

Metastasis of GC cells into neighboring and distant tissues is an increasing challenge. Understanding underlying molecular pathways involved in this malignancy can pave the road to effective GC therapy. Thanks to newly conducted researches in this field, it has been reported that epithelial-to-mesenchymal transition (EMT) and angiogenesis are two vital factors that promote the migration of GC cells. Transformation of epithelial cells into mesenchymal ones is performed during the EMT mechanism, with a reduction in E-cadherin levels (epithelial marker) and an increase in mesenchymal markers (N-cadherin and vimentin) [92,93]. On the other hand, angiogenesis not only provides energy and oxygen supplies for cancer cells, but also directs cancer cells into blood circulation and their migration into distant locations [94-96]. Thus, these two mechanisms are critical for cancer cells and harmful for patients with cancer. The PI3K/Akt signaling pathway can facilitate EMT and angiogenesis in cancer cells $[97,98]$, so targeting PI3K/Akt and its upstream mediators is of importance in cancer therapy. In GC cells, the aforementioned signaling networks are controlled by miRs. Overexpression of miR-616-3p stimulates the PI3K/Akt signaling pathway via PTEN downregulation. This accelerates the stimulation of angiogenesis via upregulation of VEGFA/VEGFR2 axis. Moreover, miR-616-3p inhibits PTEN to enhance expressions of snail, slug, and vimentin, along with a substantial decrease in E-cadherin expression [99]. In addition to migration and invasion, miRs can participate in the resistance of GC cells into apoptosis by targeting PTEN signaling. In order to improve overall survival of patients with cancer and simultaneously suppress their malignancy, induction of apoptosis is an ideal candidate. MiR-575, as an oncogene factor, reduces the expression of PTEN, to diminish apoptosis in GC cells [92]. Although this study has not examined the expression of PI3K/Akt, it appears that resistance of GC cells into apoptosis in previous studies was due to activation of the PI3K/Akt signaling pathway.

As a miR with antitumor activity, miR-136 can induce apoptosis via downregulation of Bcl-2 [100]. In addition to proliferation, miR-136 interferes with migration of GC cells via the inhibition of HOXC10 [101]. Although these studies advocate for an onco-suppressor role of miR-136 in GC, a recent study has confirmed that miR-136 functions as an oncogene factor via targeting PTEN in GC cells. It seems that miR-136 downregulates the expression of PTEN, to elevate the viability and migration of GC cells. It is worth mentioning that miR-136 has no effect on Akt, and it just affects phosphorylated Akt in GC cells [102]. Therefore, targeting such miRs can lead to suppressing GC progression and development. An experiment has performed such a strategy in GC therapy. Silencing miR-21 is associated with stimulation of apoptosis and cell cycle arrest in GC cells. This is due to the upregulation of PTEN at the protein level and subsequent inhibition of Akt phosphorylation at Thr308 and Ser473 [103].

It is worth noting that the relationship between miRs and PTEN signaling can determine tumor stage and its advancement. In GC cells in which miR-205-5p undergoes upregulation, while a reduction occurs in expression of PTEN, tumor cells are in advanced stages. Downregulation of miR-250-5p enhances expression of PTEN, which mediates apoptosis induction and tumor-growth inhibition [104]. Taking everything into account, studies demonstrate that oncogene miRs bind to $3^{\prime}$-UTR of PTEN to negatively affect its expression. The decrease in expression of PTEN leads to the resistance of GC cells into apoptosis, their enhanced proliferation, high metastatic capability, and poor prognosis of patients with GC (Table 1) [99,105]. 
Table 1. Regulation of PTEN and its downstream targets by miRs in gastric cancer (GC) cells.

\begin{tabular}{|c|c|c|c|}
\hline MiR & Molecular Signaling & Results & References \\
\hline MiR-28 & PTEN/PI3K/Akt & $\begin{array}{c}\text { Downregulation of PTEN } \\
\text { Stimulation of PI3K/Akt } \\
\text { Promoting invasion and proliferation }\end{array}$ & [106] \\
\hline MiR-21 & PTEN/Akt & $\begin{array}{c}\text { Inhibition of PTEN } \\
\text { Stimulation of Akt } \\
\text { Enhancing Bcl-2/Bax ratio }\end{array}$ & {$[107,108]$} \\
\hline $\begin{array}{l}\text { MiR-26a } \\
\text { MiR-106b } \\
\text { MiR-214 }\end{array}$ & PTEN & $\begin{array}{c}\text { Decreasing PTEN expression } \\
\text { Poor prognosis } \\
\text { Low survival }\end{array}$ & [109-111] \\
\hline MiR-21 & PTEN/TGF- $\beta / \mathrm{EMT}$ & $\begin{array}{c}\text { Downregulation of PTEN } \\
\text { Induction of TGF-1/EMT axis } \\
\text { Enhancing E-cadherin levels } \\
\text { Reducing N-cadherin and vimentin levels } \\
\text { Increasing migration of cancer cells }\end{array}$ & [112] \\
\hline MiR-214 & PTEN & $\begin{array}{l}\text { Downregulation of PTEN } \\
\text { Reducing cell cycle arrest }\end{array}$ & [113] \\
\hline MiR-301a & PTEN/Wnt/ $\beta$-catenin & $\begin{array}{c}\text { Suppressing PTEN } \\
\text { Activation of Wnt signaling } \\
\text { Promoting metastasis }\end{array}$ & [114] \\
\hline
\end{tabular}

\subsubsection{MicroRNAs and PTEN Inhibition}

To date, just two studies have identified an onco-suppressor miR that affects PTEN signaling by exerting its antitumor activity, so we include it here. Phosphatidylinositol 3,4,5- trisphosphate RAC exchanger 2a (P-Rex2a) is a guanine nucleotide exchange factor (GEF) and interacts with PTEN to induce PI3K in cancer cells [115]. MiR-338-3p affects P-Rex2a in suppressing GC progression. MiR-338-3p binds to P-Rex2a and reduces its expression. This impact triggers PTEN signaling that, in turn, suppresses PI3K/Akt, leading to a decrease in proliferation and invasion of GC cells [116]. MiR/PTEN axis can activate pro-apoptotic factors in GC therapy. MiR-370 enhances expression of PTEN to inhibit Pi3K/Akt/mTOR signaling, resulting in the upregulation of caspase-3, p53, and GSK-3 $\mu$ and subsequent induction of apoptosis in GC cells [117].

\subsection{MicroRNAs, PTEN, Drug-Therapy, and Radio-Therapy}

Although much attention has been directed toward the adverse effects of chemotherapy, there is another emerging problem in cancer therapy, known as "drug resistance" [118,119]. How to overcome drug resistance is under discussion, and different methods have been mentioned, such as using poly-chemotherapy, genetic intervention, finding novel chemotherapeutic agents, and so on [120-122]. It is quite obvious that the best way to accelerate the pace for the aforementioned strategies is to reveal the molecular pathways involved in drug resistance. In this section, we provide a new insight into the involvement of miRs in regulating PTEN in the drug resistance of GC cells.

Cisplatin resistance is a troublesome problem for chemotherapy [123,124]. It is worth noting that factors that contribute to cisplatin resistance have been identified in recent years by extensive researches [125,126]. In GC cells, the miR/PTEN axis is of importance. Normally, cisplatin administration in patients with GC should improve their overall survival by induction of apoptosis in GC cells and reducing their survival and viability. However, it is held that miR-21, as an oncogene factor in GC cells, is an impediment against cisplatin-mediated apoptosis. This is due to the downregulation of PTEN by miR-21 and subsequent resistance of GC cells into cisplatin-induced apoptosis [127]. Therefore, decreasing the expression of such miRs can pave the road to the inhibition of drug resistance in GC cells. In a recent experiment, it was found that silencing miR-147 results in enhanced sensitivity of GC cells into 5-fluorouracil chemotherapy via PTEN upregulation. In fact, by overexpression of PTEN, a 
decrease occurs in PI3K/Akt that subsequently suppresses proliferation and triggers apoptosis in GC cells [128]. The involvement of the miR/PTEN axis in the drug resistance of GC cells can be attributed to their malignant behavior. To be more specific, when more cancer cells are at an advanced stage, the more they are resistant into chemotherapy $[129,130]$. Such a phenomenon can be associated with the miR/PTEN axis. In GC cells, miR-21-5p decreases PTEN expression. As it was mentioned in the introduction section, partial loss of PTEN leads to tumorigenesis and directing tumor masses into advanced stages. In this case, downregulation of PTEN by miR-21-5p triggers doxorubicin resistance via promoting malignant behavior of GC cells and facilitating their progression into advanced stages [131]. Taking everything into account, it appears that oncogene miRs such as miR-193-3p, -19a/b, -21, and -106a contribute to resistance of GC cells to chemotherapy via downregulation of PTEN and promoting their proliferation by activation of the PI3K/Akt signaling pathway [132-135].

In addition to chemoresistance, cancer cells are able to obtain resistance to radiotherapy. This feature of cancer cells has challenged the efficacy of combination therapy with chemotherapy and radiotherapy [136,137]. Thus, finding molecular pathways involved in the radio-resistance of GC cells is of importance in another dimension. Similarly, miR/PTEN participates in the radio-resistance of GC cells. It has been reported that overexpression of miR-221 and miR-222 occurs in GC cells. These miRs are able to bind into $3^{\prime}$-UTR of PTEN to inhibit its expression. Consequently, a decrease occurs in the expression of PTEN and provides the condition for the uncontrolled proliferation and migration of GC cells. This leads to the resistance of GC cells to radiotherapy [138]. Further studies can focus on downstream targets of the miR/PTEN axis in radiotherapy of GC cells.

\subsection{CircularRNAs Target PTEN}

CircularRNAs (circRNAs) are another kind of RNA molecule with a different structure from linear RNAs. In contrast to linear RNAs that have a $5^{\prime}$ cap and $3^{\prime}$ tail, circRNAs are closed-loop structures with covalent bonds that have $5^{\prime}-3^{\prime}$ polarities or polyadenylated tails [139]. After the discovery of circRNAs in 1970, it was believed that these kinds of RNAs emanate from errors in alternative splicing, since they have low expression [140-142]. However, further research demonstrated that circRNAs are a distinct type of RNA molecule with modulatory effects on cellular events [143-146]. In the case of PTEN signaling, different experiments have shown that circRNAs are able to act as upstream mediators of the PTEN signaling pathway in cancer cells [147-149]. This section is devoted to investigating the role of circRNAs in the regulation of PTEN in GC cells.

In GC cells, circRNAs can regulate PTEN to dually inhibit or promote the proliferation and invasion of cancer cells. A newly published experiment has shown that circRNA ZFR is an oncogene factor that reduces expression of miR-101-3p to enhance the malignancy of cancer cells [150]. A similar phenomenon occurs in GC cells, so that circRNA ZFR regulates miR expression to affect PTEN signaling. By binding into miR-130a and miR-107, circRNA ZFR reduces their expression to facilitate overexpression of PTEN in GC cells. Then, a decrease occurs in the viability of GC cells via upregulation of PTEN and stimulation of apoptosis [151]. On the other hand, there are circRNAs that downregulate PTEN signaling in ensuring malignant behavior of GC cells. CiRS-7 is considered to be an oncogene circRNA in GC cells that considerably elevates growth by sponging miR-7 and subsequent activation of HOXB13 [152]. Moreover, CiRS-7 can promote the migration of cancer cells by downregulation of miR-1299 and upregulation of matrix metalloproteinases (MMPs) [153]. These studies demonstrate the stimulatory effect of CiRS-7 on cancer cells, and a same role is observed in GC cells via targeting the PTEN/PI3K/Akt signaling pathway. In GC cells, CiRS-7 downregulates the expression of miR-7 as an onco-suppressor factor. Therefore, the PI3K/Akt signaling pathway is activated via PTEN downregulation, leading to the increased proliferation and invasion of GC cells [154].

CircRNA LARP4 is another onco-suppressor factor in cancer. This circRNA suppresses both growth and metastasis of cancer cells via downregulation of miR-424-5p [155]. In respect to antitumor role of LARP4, low expression of this circRNA is correlated with poor prognosis of patients with cancer [156]. Therefore, enhancing expression of circRNA LARP4 can provide condition for a decrease 
in viability of cancer cells [157]. There is a reverse relationship between circRNA LARP4 and miR-1323 in GC cells. MiR-1323 expression demonstrates a decrease by activity of LARP4. Then, PTEN signaling is activated to suppress the PI3K/Akt axis, resulting in the decreased progression of GC cells [158]. MiR-130a-3p is another oncogene factor in GC cells, and its expression is affected by onco-suppressor circGRAMD1B. This circRNA reduces expression of miR-130a-3p via sponging to promote expression of PTEN. Then, the condition for interaction of PTEN and p21 is provided to suppress the malignancy of GC cells [159]. Overall, these studies are in agreement with the fact that circRNAs are efficient upstream mediators of PTEN signaling in GC cells, and further studies should be performed to reveal more circRNAs capable of regulating PTEN.

\subsection{LncRNAs Target PTEN}

In addition to miRs and circRNAs, the role of IncRNAs in the regulation of PTEN in GC cells has been investigated. LncRNAs are ncRNAs with more than 200 nucleotides and biological functions in both normal and cancerous cells [160-162]. LncRNAs-mediated regulation of PTEN is of importance in cancer cells, and understanding the relationship between lncRNAs, PTEN signaling, and mediators can broaden our insight toward their regulation in further experiments, and suppressing cancer malignancy $[66,163,164]$. In this section, our aim is to provide a mechanistic discussion about regulation of PTEN by lncRNAs in GC cells. In the previous section, we demonstrated that circRNAs and miRs are able to function as upstream mediators of PTEN in GC cells. The role of lncRNAs in regulation of PTEN in GC cells has been more examined compared to circRNAs. Thus, it would be possible to discuss more molecular pathways.

The expression of onco-suppressor lncRNAs undergoes downregulation in cancer cells. LncRNA SLC25A5-AS1 has low expression in GC cells, and this leads to a decrease in apoptotic cell death. SLC25A5-AS1 reduces the expression of miR-19a-3p via acting as an endogenous competitor. MiR-19a-3p decreases the response of GC cells to apoptosis via downregulation of PTEN and subsequent activation of the PI3K/Akt signaling pathway. SLC25A5-AS1 induces PTEN expression via miR-19a-3p downregulation, to interfere with activation of the PI3K/Akt signaling pathway. This directs GC cells toward apoptosis [146]. In fact, onco-suppressor lncRNAs protect PTEN from repression by negatively targeting miRs. For instance, IncRNA PTENP1 functions as competing endogenous RNAs (ceRNAs) to downregulate miR-106b and miR-93. As a consequence, PTEN is activated to exert its inhibitory effect of GC cells [165].

LncRNAs can lead to enhanced metastasis of GC cells by inhibition of PTEN. This can be related to downstream targets of PI3K/Akt that play a significant role in enhancing the migratory ability of cancer cells. As we mentioned earlier, the migratory ability of cancer cells is significantly accelerated by the EMT mechanism [166]. Slug is one of the regulators of EMT, and its upregulation can stimulate EMT and provide invasion of cancer cells [167]. LncRNA GPR65-1 is an oncogene factor in GC cells that can stimulate the migration of GC cells. LncRNA GPR65-1 stimulates Akt signaling via PTEN downregulation. Then, slug undergoes upregulation in GC cells to induce invasion and metastasis of GC cells [168]. These studies demonstrate that (1) lncRNAs are efficient upstream mediators of PTEN in GC cells, (2) they can affect upstream mediators of PTEN such as miRs, and (3) they dually affect proliferation and invasion of GC cells. Table 2 summarizes lncRNAs regulating PTEN in GC cells. 
Table 2. LncRNAs regulating PTEN in GC cells and their relationship with proliferation and invasion.

\begin{tabular}{|c|c|c|c|}
\hline LncRNA & Signaling Network & Results & References \\
\hline PCAT18 & MiR-107/PTEN/PI3K/Akt & $\begin{array}{c}\text { Downregulation of miR-107 by PCAT18 } \\
\text { Stimulation of PTEN signaling } \\
\text { Inhibition of PI3K/Akt } \\
\text { Inducing tumor growth inhibition }\end{array}$ & [169] \\
\hline TUBA4B & $\begin{array}{c}\text { MiR-214/PTEN } \\
\text { MiR-216a/b-PTEN }\end{array}$ & $\begin{array}{c}\text { Downregulation of } \mathrm{miR}-214 \text { and } \\
\text { miR-216a/b } \\
\text { Stimulation of PTEN } \\
\text { Suppressing proliferation and migration }\end{array}$ & [170] \\
\hline DGCR5 & MiR-23b/PTEN & $\begin{array}{l}\text { Inhibition of miR-23b } \\
\text { Stimulation of PTEN } \\
\text { Induction of apoptosis }\end{array}$ & [171] \\
\hline LINC00470 & PTEN & $\begin{array}{l}\text { Reducing PTEN stability and directing it } \\
\text { into degradation } \\
\text { Enhancing proliferation and invasion }\end{array}$ & [172] \\
\hline AFAP1-AS1 & PTEN/Akt & $\begin{array}{c}\text { Reducing PTEN expression } \\
\text { Stimulation of Akt } \\
\text { Downregulation of pro-apoptotic factors } \\
\text { PARP1, capase-3 and caspase-9 }\end{array}$ & [173] \\
\hline HOTAIRM1 & MiR-17-5p/PTEN & $\begin{array}{l}\text { Inhibition of miR-17-5p expression via } \\
\text { sponging } \\
\text { Upregulation of PTEN } \\
\text { Decreasing viability and proliferation }\end{array}$ & [174] \\
\hline FER1L4 & MiR-106a-5p/PTEN & $\begin{array}{l}\text { Inhibition of miR-106a-5p } \\
\text { Stimulation of PTEN } \\
\text { Disrupting proliferation }\end{array}$ & [175] \\
\hline HOTAIR & MiR-17-5p/PTEN & $\begin{array}{l}\text { Upregulation of miR-17-5p by HOTAIR } \\
\text { Inhibition of PTEN } \\
\text { Enhancing chemoresistance }\end{array}$ & [167] \\
\hline PCAT1 & EZH2/PTEN & $\begin{array}{l}\text { Increasing EZH2 expression } \\
\text { Downregulation of PTEN } \\
\text { Stimulation of cisplatin resistance }\end{array}$ & [176] \\
\hline
\end{tabular}

\section{Antitumor Compounds Target PTEN}

In the previous sections, we provided a comprehensive discussion about regulation of PTEN signaling by epigenetic factors such as miRs, circRNAs, and lncRNAs. Among them, lncRNAs and miRs have been studied more than circRNAs, showing that there is still a long way to go for finding the exact relationship between circRNAs and PTEN in GC cells. However, it seems that epigenetic factors are not the only ones that can regulate PTEN signaling in GC cells. Increasing evidence highlights that fact that antitumor compounds, particularly natural products, are capable of regulation of PTEN in different cancers $[177,178]$. This story has been repeated for GC, and the aim of this section is to shed some light on regulation of PTEN in GC cells by antitumor compounds.

Curcumin is a polyphenol and natural product isolated from root of turmeric rhizome [179-181]. It has pharmacological activities for the amelioration of cardiovascular disorders [182], improving blood lipids [183], reducing the risk of diabetes development [184,185], and so on. However, among them, antitumor activity of curcumin is of importance, since curcumin has been able to suppress proliferation of cancer cells, induce apoptosis, and inhibit their migration [167,186,187]. Curcumin can negatively affect proliferation of GC cells via targeting PTEN signaling. In affecting PTEN signaling, curcumin can target its upstream mediator, miR-21. Inhibition of GC proliferation by curcumin is timeand dose-dependent. Administration of curcumin $(5-40 \mu \mathrm{M})$ reduces expression of miR-21 to activate PTEN signaling (highest effect in high doses of curcumin). Then, Akt undergoes downregulation to 
suppress proliferation of GC cells [188]. To date, just one study has evaluated the efficacy of curcumin in targeting PTEN signaling in GC cells, and more studies will reveal different molecular pathways of curcumin action in targeting PTEN in GC cells.

Resveratrol (Res) is also a polyphenol agent and well-known in traditional Chinese medicine [189,190]. It is extracted from Polygonum cuspidatum and exclusively applied as a chemotherapeutic agent in the treatment of different cancers [191]. The antitumor activity of Res emanates from its effect on different molecular pathways, such as Wnt [192], miRs [193,194], and so on. Two studies have investigated the antitumor activity of Res against GC via targeting PTEN signaling. Administration of Res (100-400 $\mu \mathrm{M}$ ) results in a decrease in p-PTEN (inactive) form in a dose-dependent manner (highest effect at $200 \mu \mathrm{M}$ ). This leads to suppression of the PI3K/Akt signaling pathway and subsequent stimulation of cell cycle arrest at G0/G1 phase [195]. As it was mentioned earlier, EMT and the migratory ability of cancer cells have a positive relationship [196,197]. EMT activation is correlated with the resistance of cancer cells to chemotherapy $[198,199]$. Thus, the inhibition of EMT is of interest in sensitizing cancer cells into inhibitory effects of chemotherapeutic agents. Administration of Res (50 and $100 \mathrm{mg} / \mathrm{L}$ ) induces PTEN to downregulate PI3K/Akt signaling. Then, epithelial marker E-cadherin level demonstrates an increase, while levels of vimentin and $\beta$-catenin as mesenchymal markers decrease, showing the inhibition of EMT by Res as a result of PTEN activation. This leads to enhanced sensitivity of GC cells to doxorubicin chemotherapy (Table 3) [200].

In regard to the regulation of PTEN by antitumor agents in GC therapy, the following outcomes may occur:

- The antitumor compounds are able to affect PTEN in a time- and dose-dependent manners,

- They can induce PTEN signaling [201-203],

- They suppress the PI3K/Akt signaling pathway [204],

- They are capable of regulating upstream mediators of PTEN, such as HDAC1 [205],

- They inhibit the development of chemoresistance in GC cells [206],

- And, finally, they interfere with proliferation and invasion of GC cells via targeting PTEN [207].

Table 3. Antitumor compounds targeting PTEN in GC therapy.

\begin{tabular}{|c|c|c|c|c|}
\hline Antitumor Agent & Concentration and Time & In Vitro/In Vivo & Results & References \\
\hline Geridonin & $10 \mu \mathrm{M}$ for $24 \mathrm{~h}$ & $\begin{array}{l}\text { In vitro (MGC } 803 \\
\text { cell line) }\end{array}$ & $\begin{array}{c}\text { Stimulation of PTEN } \\
\text { Downregulation of PI3K/Akt } \\
\text { signaling } \\
\text { Accumulation of p53 } \\
\text { Stimulation of apoptosis }\end{array}$ & [208] \\
\hline Ursolic acid & $0-35 \mu \mathrm{M}$ for $24 \mathrm{~h}$ & $\begin{array}{l}\text { In vitro (SGC-7901 } \\
\text { cells) }\end{array}$ & $\begin{array}{c}\text { PTEN activation } \\
\text { Translocation of cofilin-1 from } \\
\text { cytoplasm to mitochondria } \\
\text { Stimulation of apoptosis }\end{array}$ & [209] \\
\hline Baicalein & $0-80 \mu \mathrm{M}$ for 24 and $48 \mathrm{~h}$ & In vitro (AGS cells) & $\begin{array}{c}\text { Activation of PTEN } \\
\text { Suppressing hypoxia mediated } \\
\text { Akt } \\
\text { Inhibition of glycolysis }\end{array}$ & [210] \\
\hline Genistein & $10-80 \mu \mathrm{moL} / \mathrm{L}$ for $24 \mathrm{~h}$ & $\begin{array}{l}\text { In vitro (SGC-7901 } \\
\text { and BGC-823 cells) }\end{array}$ & $\begin{array}{c}\text { Upregulation of PTEN } \\
\text { Stimulation of G2/M arrest }\end{array}$ & [211] \\
\hline Methylxanthine & $\begin{array}{c}\text { Different doses (in vitro) } \\
\text { for } 12 \text { and } 24 \mathrm{~h} \\
4 \text { and } 8 \mathrm{mmoL} / \mathrm{L} \text { for } \\
24 \text { days }\end{array}$ & $\begin{array}{l}\text { In vitro (MGC-803 } \\
\text { cells) } \\
\text { In vivo (model of } \\
\text { GC) }\end{array}$ & $\begin{array}{c}\text { Stimulation of PTEN } \\
\text { Inhibition of PI3K/Akt/mTOR } \\
\text { signaling } \\
\text { Suppressing proliferation and } \\
\text { migration }\end{array}$ & [212] \\
\hline
\end{tabular}

\section{Upstream Modulators of PTEN}

\subsection{Proliferation of Gastric Cancer Cells}

Cytotoxin-associated gene A ( $\mathrm{CagA})$ is considered to be a factor related to gastric disorders such as peptic ulcer disease [213]. Clinical studies have also confirmed the involvement of CagA 
in gastrointestinal disorders, so that, in an experiment conducted by Weel and colleagues, it was found that $85-100 \%$ of patients with duodenal ulcer have an infection with CagA + Helicobacter pylori (H. pylori) [214]. The role of CagA in GC has been associated with its effect on PTEN. The expression of PTEN undergoes downregulation in GC cells and tissues, while CagA has high expression in these malignant cells. Investigation of molecular signaling pathways demonstrates that CagA reduces expression of PTEN by enhancing DNA methylation and directing GC cells into uncontrolled proliferation [215]. Arginine/serine-rich coiled coil 1 (RSRC1) gene has been located on chromosome 3, and it encodes a protein containing arginine and serine components. The products of this gene are involved in cellular evens and are able to modulate transcription process [216,217]. RSRC1 participates in suppressing the uncontrolled growth of GC cells via upregulation of PTEN [218]. Thus, enhancing expression of RSRC1 as an upstream mediator of PTEN can be considered as a potential strategy in GC therapy. In suppressing the proliferation of GC cells, PI3K/Akt, as a downstream target of PTEN, should be inhibited. Downregulation of PTEN in GC cells occurs as a result of its phosphorylation at S380/T382/T383 cluster. Upstream mediators of PTEN signaling with onco-suppressor activity such as PDZK1 are able to inhibit PTEN phosphorylation, enhance its stability, and suppress the PI3K/Akt signaling pathway, resulting in the reduced proliferation of GC cells [219].

In addition to having physiological roles such as embryogenesis and T-cell activation, WWP2's oncogene role in cancer cells is being revealed by accumulating data. It is an E3 ligase of PTEN and contributes to carcinogenesis via PI3K/Akt activation [220-228]. In GC cells, WWP2 enhances the growth and viability of cancer cells via the downregulation of PTEN. Silencing of WWP2 leads to stimulation of PTEN and subsequent a decrease in the proliferation of GC cells [229]. It is worth mentioning that most of the studies have focused on onco-suppressor mediators of PTEN in GC. Krüppel-like factors (KLFs) are able to affect different cellular events via acting as transcription regulators [230-232]. The exact role of KLFs in cancers has not been understood, and it seems that KLFs function as oncogene or onco-suppressor factors in respect to the tissue context, the cancer type, or its stage [233]. However, KLFs exert antitumor activity via the regulation of PTEN. The in vitro and in vivo experiments demonstrate that KLFs impair the PI3K/Akt signaling pathway via PTEN upregulation, to induce apoptosis and cell cycle arrest in GC cells [234]. Taking everything into account, studies exhibit that upstream mediators of PTEN are able to disrupt viability and growth of GC cells, and more studies are needed to clarify the relationship between PTEN and its upstream mediator, as well as to find more upstream mediators [235-238].

\subsection{Metastasis of Gastric Cancer Cells}

Note that there have been studies focusing on the relationship between PTEN and its upstream mediators in metastasis of GC cells. In fact, the process of metastasis accounts for a significant number of deaths among different cancer patients, including those suffering from gastric cancer [239,240]. Each experiment has evaluated a novel axis that is of importance for effective GC therapy. In this section, we provide an integrated discussion about the regulation of PTEN by these molecular pathways.

Ten-Eleven Translocation 1 (TET1) is an enzyme contributing to the conversion of 5-methylcytosine to 5-hydroxymethylcytosine. TET1 participates in demethylation of CpG islands and, in this way, activates its downstream targets. Increasing evidence demonstrates the loss of TET1 in different cancers, particularly GC [241-245]. Overexpression of TET1 inhibits Akt signaling via PTEN downregulation to suppress metastasis of GC cells [246]. The metastasis of GC cells is associated with poor survival of patients. Suppressing an invasion of GC cells not only improves overall survival of patients with GC, but can also promote the efficacy of antitumor agents in eradicating cancer cells. Therefore, there is an urgent need for revealing molecular pathways involved in metastasis of GC cells and their further targeting. As it was mentioned earlier, EMT is associated with the migration of cancer cells [44,93]. In GC cells, the interaction between EZH2 and PTEN signaling provides the condition for enhancing invasion. EZH2 attaches to the promoter of PTEN to decrease its expression. Then, the EMT mechanism 
is activated via Akt signaling [247]. The EZH2/PTEN/Akt/EMT axis can be targeted in further studies to overcome GC.

As a potential factor in cell fate, increasing evidence has shown that Notch signaling plays like a double-edged sword in cancer, and it has both oncogene and onco-suppressor activities [248-254]. It has been reported that metastasis of GC cells is tightly regulated by Notch/PTEN/Akt axis. In promoting the invasion of GC cells, Notch signaling stimulates Akt via PTEN downregulation. Using siRNA, Notch signaling was inhibited, leading to a dramatic reduction in metastasis of GC cells [255]. Studies related to PTEN regulation reveal that oncogene factors downregulate PTEN, to induce the PI3K/Akt signaling pathway. A further step is related to the downstream targeting of Akt signaling, so that, as it was mentioned in this section, EMT can be induced to ensure metastasis of cancer cells. More studies will provide more underlying molecular pathways in this process $[124,256]$.

\subsection{Drug Resistance of Gastric Cancer Cells}

The regulation of PTEN by upstream molecular pathways can also lead to the emergence of chemoresistance of malignant gastric cancer cells. Akt is also known as PKB and can support cancer cells against apoptotic cell death. Increasing evidence demonstrates that Akt-induced pro-survival pathways mediate chemoresistance of cancer cells [257-259]. The overexpression of Akt is correlated with the downregulation of PTEN. This provides a condition for resistance of GC cells to chemotherapeutic agents such as 5-fluorouracil, Adriamycin, mitomycin, and cis-platinum [260]. To date, just one study has evaluated the regulation of PTEN by other molecular pathways (except miRs, lncRNAs, and circRNAs) in the induction of chemoresistance. More studies are required to discover novel pathways involved in the chemoresistance of GC cells via PTEN regulation.

\section{Activation and Deactivation of PTEN in Gastric Cancer}

With respect to the role of PTEN in suppressing both proliferation and invasion of GC cells, any impairment in this signaling can lead to tumorigenesis. We mentioned in the introduction that a partial loss in PTEN expression can result in the development of different cancers. This story is also true for GC. In previous sections, we mechanistically investigated the regulation of PTEN in GC cancer. It is quite obvious that PTEN downregulation enhances the proliferation of GC cells, and one of the most common downstream targets of PTEN is the PI3K/Akt signaling pathway. It has been reported that inactivation of PTEN in GC cells leads to the stimulation of PI3K/Akt signaling and subsequent increase in proliferation [261]. The PTEN loss is a positive factor for enhanced invasion of GC cells [262]. Activation of PTEN signaling remarkably diminishes tumor growth [263]. Moreover, enhancing the expression of PTEN can pave the road to suppressing the migration of GC cells [264]. Clinical studies have confirmed the role of PTEN in the detection of GC. It seems that PTEN loss ensures the advanced stage of GC [265]. All of these studies demonstrate that (1) PTEN is an onco-suppressor factor, and (2) modulation of its expression is of importance in GC therapy (Figure 2) [266,267]. 


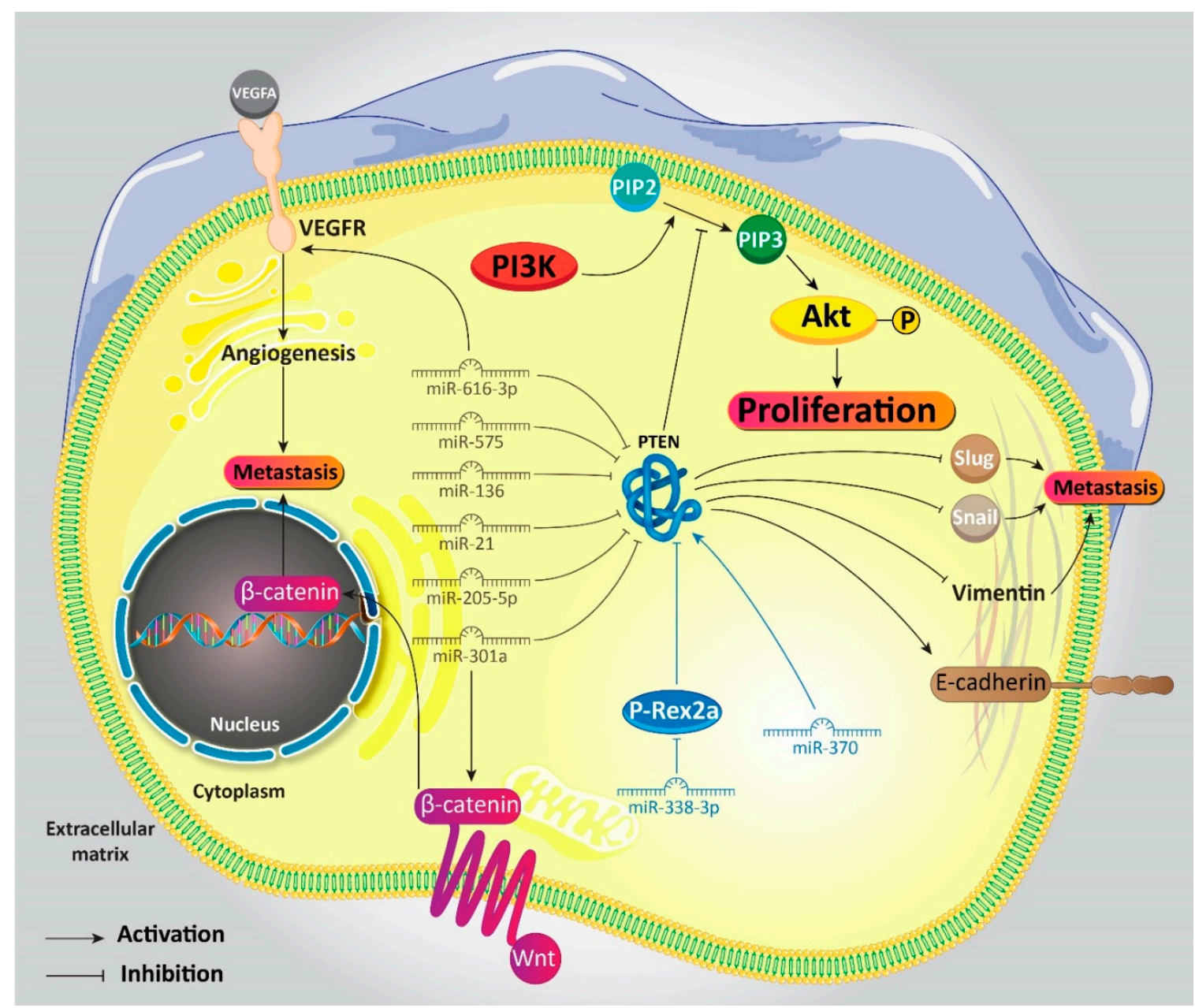

Figure 2. Activation/inactivation of PTEN in gastric cancer and its involvement in proliferation and metastasis of these malignant cells.

\section{Conclusions and Remarks}

What we discussed in this work is the onco-suppressor role of PTEN signaling. PI3K/Akt is the most common downstream target of PTEN in suppressing both proliferation and invasion of cancer cells. However, other molecular pathways such as FAK can be targeted by tumor suppressor PTEN. MiRs, lncRNAs, and circRNAs are able to function as upstream mediators of PTEN in GC cells. Moreover, antitumor compounds can affect PTEN (upregulation) to inhibit proliferation and invasion of GC cells. The interesting point is the relationship between PTEN and EMT mechanism in GC cells. As it was mentioned, migration of GC cells into neighboring and distant cells and tissues significantly reduces overall survival of patients with cancer. PTEN can inhibit the EMT mechanism by targeting PI3K/Akt signaling pathway that we described in the text. It seems that we are at the beginning point of knowing the molecular pathways by which PTEN affects proliferation and malignancy of GC cells. Furthermore, there is still much space for progress about understanding new upstream mediators of PTEN signaling. SiRNA and CRISPR/Cas9, as powerful editing tools, can be used to modulate the expression of PTEN in GC cells. Newer antitumor drugs can also be introduced into the regulation of PTEN in GC cells.

Funding: A.P.K. is supported by the National Medical Research Council of Singapore. A.P.K. is also supported by the National Medical Research Council of Singapore and the Singapore Ministry of Education, under its Research Centres of Excellence initiative to Cancer Science Institute of Singapore, National University of Singapore. 
Conflicts of Interest: The authors declare no conflict of interest. The funders had no role in the design of the study; in the collection, analyses, or interpretation of data; in the writing of the manuscript, or in the decision to publish the results.

$\begin{array}{ll}\text { Abbreviations } \\ \text { PTEN } & \text { phosphatase and tensin homolog } \\ \text { GC } & \text { gastric cancer } \\ \text { PIP2 } & \text { phosphatidylinositol 4-5-diphosphate } \\ \text { TRPV4 } & \text { transient receptor potential vanilloid type 4 } \\ \text { NF-B } & \text { nuclear factor-kappaB } \\ \text { lncRNA } & \text { long non-coding RNA } \\ \text { pCR } & \text { pathologic complete response } \\ \text { ncRNAs } & \text { non-coding RNAs } \\ \text { EMT } & \text { epithelial-to-mesenchymal transition } \\ \text { GEF } & \text { guanine nucleotide exchange factor } \\ \text { circRNAs } & \text { circular RNAs } \\ \text { MMPs } & \text { matrix metalloproteinases } \\ \text { ceRMAs } & \text { competing endogenous RNAs } \\ \text { Res } & \text { resveratrol } \\ \text { CagA } & \text { cytotoxin-associated gene A } \\ \text { H. pylori } & \text { Helicobacter pylori } \\ \text { RSRC1 } & \text { arginine/serine-rich coiled coil-1 } \\ \text { KLFs } & \text { Krüppel-like factors } \\ \text { TET1 } & \text { Ten-Eleven Translocation 1 }\end{array}$

\section{References}

1. Islami, F.; Siegel, R.L.; Jemal, A. The changing landscape of cancer in the USA-Opportunities for advancing prevention and treatment. Nat. Rev. Clin. Oncol. 2020,1-19. [CrossRef]

2. Yue, B.; Song, C.; Yang, L.; Cui, R.; Cheng, X.; Zhang, Z.; Zhao, G. METTL3-mediated N6-methyladenosine modification is critical for epithelial-mesenchymal transition and metastasis of gastric cancer. Mol. Cancer 2019, 18, 142. [CrossRef]

3. Fang, X.; Wen, J.; Sun, M.; Yuan, Y.; Xu, Q. CircRNAs and its relationship with gastric cancer. J. Cancer 2019, 10, 6105-6113. [CrossRef]

4. Jeong, M.H.; Park, S.Y.; Lee, S.H.; Seo, J.; Yoo, J.Y.; Park, S.H.; Kim, M.J.; Lee, S.; Jang, S.; Choi, H.K.; et al. EPB41L5 Mediates TGFß-Induced Metastasis of Gastric Cancer. Clin. Cancer Res. 2019, 25, 3617-3629. [CrossRef]

5. Yang, F.; Hu, A.; Li, D.; Wang, J.; Guo, Y.; Liu, Y.; Li, H.; Chen, Y.; Wang, X.; Huang, K.; et al. Circ-HuR suppresses HuR expression and gastric cancer progression by inhibiting CNBP transactivation. Mol. Cancer 2019, 18, 158. [CrossRef]

6. Qin, Z.Y.; Wang, T.; Su, S.; Shen, L.T.; Zhu, G.X.; Liu, Q.; Zhang, L.; Liu, K.W.; Zhang, Y.; Zhou, Z.H.; et al. BRD4 Promotes Gastric Cancer Progression and Metastasis through Acetylation-Dependent Stabilization of Snail. Cancer Res. 2019, 79, 4869-4881. [CrossRef] [PubMed]

7. Zhang, S.; Yang, Y.; Huang, S.; Deng, C.; Zhou, S.; Yang, J.; Cao, Y.; Xu, L.; Yuan, Y.; Yang, J.; et al. SIRT1 inhibits gastric cancer proliferation and metastasis via STAT3/MMP-13 signaling. J. Cell. Physiol. 2019, 234, 15395-15406. [CrossRef] [PubMed]

8. Feng, W.; Ding, Y.; Zong, W.; Ju, S. Non-coding RNAs in regulating gastric cancer metastasis. Clin. Chim. Acta Int. J. Clin. Chem. 2019, 496, 125-133. [CrossRef]

9. Zhang, J.; Guo, S.; Piao, H.Y.; Wang, Y.; Wu, Y.; Meng, X.Y.; Yang, D.; Zheng, Z.C.; Zhao, Y. ALKBH5 promotes invasion and metastasis of gastric cancer by decreasing methylation of the lncRNA NEAT1. J. Physiol. Biochem. 2019, 75, 379-389. [CrossRef]

10. Chen, E.B.; Qin, X.; Peng, K.; Li, Q.; Tang, C.; Wei, Y.C.; Yu, S.; Gan, L.; Liu, T.S. HnRNPR-CCNB1/CENPF axis contributes to gastric cancer proliferation and metastasis. Aging 2019, 11, 7473-7491. [CrossRef] 
11. Liu, Y.; Li, Y.; Zhao, Y.; Liu, Y.; Fan, L.; Jia, N.; Zhao, Q. ILF3 promotes gastric cancer proliferation and may be used as a prognostic marker. Mol. Med. Rep. 2019, 20, 125-134. [CrossRef] [PubMed]

12. Zhang, J.; Jin, H.Y.; Wu, Y.; Zheng, Z.C.; Guo, S.; Wang, Y.; Yang, D.; Meng, X.Y.; Xu, X.; Zhao, Y. Hypoxia-induced LncRNA PCGEM1 promotes invasion and metastasis of gastric cancer through regulating SNAI1. Clin. Transl. Oncol. 2019, 21, 1142-1151. [CrossRef] [PubMed]

13. Qi, Y.; Lv, J.; Liu, S.; Sun, L.; Wang, Y.; Li, H.; Qi, W.; Qiu, W. TSPAN9 and EMILIN1 synergistically inhibit the migration and invasion of gastric cancer cells by increasing TSPAN9 expression. BMC Cancer 2019, 19, 630. [CrossRef] [PubMed]

14. Li, Y.; Sun, Q.; Jiang, M.; Li, S.; Zhang, J.; Xu, Z.; Guo, D.; Gu, T.; Wang, B.; Xiao, L.; et al. KLF9 suppresses gastric cancer cell invasion and metastasis through transcriptional inhibition of MMP28. FASEB J. 2019, 33, 7915-7928. [CrossRef]

15. Ashrafizadeh, M.; Zarrabi, A.; Samarghandian, S.; Najafi, M. PTEN: What we know of the function and regulation of this onco-suppressor factor in bladder cancer? Eur. J. Pharmacol. 2020, 173226. [CrossRef] [PubMed]

16. Salvatore, L.; Calegari, M.A.; Loupakis, F.; Fassan, M.; Di Stefano, B.; Bensi, M.; Bria, E.; Tortora, G. PTEN in Colorectal Cancer: Shedding Light on Its Role as Predictor and Target. Cancers 2019, 11, 1765. [CrossRef]

17. Luongo, F.; Colonna, F.; Calapà, F.; Vitale, S.; Fiori, M.E.; De Maria, R. PTEN tumor-suppressor: The dam of stemness in cancer. Cancers 2019, 11, 1076. [CrossRef]

18. Álvarez-Garcia, V.; Tawil, Y.; Wise, H.M.; Leslie, N.R. Mechanisms of PTEN loss in cancer: It's all about diversity. Semin. Cancer Biol. 2019, 59, 66-79. [CrossRef]

19. Huang, Y.; Wang, H.; Hao, Y.; Lin, H.; Dong, M.; Ye, J.; Song, L.; Wang, Y.; Li, Q.; Shan, B.; et al. Myeloid PTEN promotes chemotherapy-induced NLRP3-inflammasome activation and antitumour immunity. Nat. Cell Biol. 2020, 22, 716-727. [CrossRef]

20. Lee, Y.R.; Chen, M.; Lee, J.D.; Zhang, J.; Lin, S.Y.; Fu, T.M.; Chen, H.; Ishikawa, T.; Chiang, S.Y.; Katon, J.; et al. Reactivation of PTEN tumor suppressor for cancer treatment through inhibition of a MYC-WWP1 inhibitory pathway. Science 2019, 364. [CrossRef]

21. Peng, W.; Chen, J.Q.; Liu, C.; Malu, S.; Creasy, C.; Tetzlaff, M.T.; Xu, C.; McKenzie, J.A.; Zhang, C.; Liang, X.; et al. Loss of PTEN Promotes Resistance to T Cell-Mediated Immunotherapy. Cancer Discov. 2016, 6, 202-216. [CrossRef] [PubMed]

22. Zhang, L.; Zhang, S.; Yao, J.; Lowery, F.J.; Zhang, Q.; Huang, W.C.; Li, P.; Li, M.; Wang, X.; Zhang, C.; et al. Microenvironment-induced PTEN loss by exosomal microRNA primes brain metastasis outgrowth. Nature 2015, 527, 100-104. [CrossRef] [PubMed]

23. Chen, G.; Sun, L.; Han, J.; Shi, S.; Dai, Y.; Liu, W. RILPL2 regulates breast cancer proliferation, metastasis, and chemoresistance via the TUBB3/PTEN pathway. Am. J. Cancer Res. 2019, 9, 1583-1606.

24. Gkountakos, A.; Sartori, G.; Falcone, I.; Piro, G.; Ciuffreda, L.; Carbone, C.; Tortora, G.; Scarpa, A.; Bria, E.; Milella, M. PTEN in lung cancer: Dealing with the problem, building on new knowledge and turning the game around. Cancers 2019, 11, 1141. [CrossRef] [PubMed]

25. Alimonti, A.; Carracedo, A.; Clohessy, J.G.; Trotman, L.C.; Nardella, C.; Egia, A.; Salmena, L.; Sampieri, K.; Haveman, W.J.; Brogi, E. Subtle variations in Pten dose determine cancer susceptibility. Nat. Genet. 2010, 42, 454. [CrossRef] [PubMed]

26. Shen-Li, H.; Koujak, S.; Szablocs, M.; Parsons, R. Reduction of Pten dose leads to neoplastic development in multiple organs of PtenshRNA mice. Cancer Biol. Ther. 2010, 10, 1194-1200. [CrossRef]

27. Furnari, F.B.; Huang, H.S.; Cavenee, W.K. The phosphoinositol phosphatase activity of PTEN mediates a serum-sensitive G1 growth arrest in glioma cells. Cancer Res. 1998, 58, 5002-5008.

28. Kotelevets, L.; van Hengel, J.; Bruyneel, E.; Mareel, M.; Van Roy, F.; Chastre, E. The lipid phosphatase activity of PTEN is critical for stabilizing intercellular junctions and reverting invasiveness. J. Cell Biol. 2001, 155, 1129-1136. [CrossRef]

29. Morais, C.E.; Gurgel, D.C.; Teixeira, A.C.; Mattos, T.V.A.; Silva, A.; Tavora, F. Prevalence of ERG expression and PTEN loss in a Brazilian prostate cancer cohort. Braz. J. Med. Biol. Res. 2019, 52, e8483. [CrossRef]

30. Carbognin, L.; Miglietta, F.; Paris, I.; Dieci, M.V. Prognostic and Predictive Implications of PTEN in Breast Cancer: Unfulfilled Promises but Intriguing Perspectives. Cancers 2019, 11, 1401. [CrossRef] 
31. Baek, S.H.; Ko, J.H.; Lee, J.H.; Kim, C.; Lee, H.; Nam, D.; Lee, J.; Lee, S.G.; Yang, W.M.; Um, J.Y.; et al. Ginkgolic Acid Inhibits Invasion and Migration and TGF- $\beta$-Induced EMT of Lung Cancer Cells Through PI3K/Akt/mTOR Inactivation. J. Cell. Physiol. 2017, 232, 346-354. [CrossRef] [PubMed]

32. Mohan, C.D.; Srinivasa, V.; Rangappa, S.; Mervin, L.; Mohan, S.; Paricharak, S.; Baday, S.; Li, F.; Shanmugam, M.K.; Chinnathambi, A.; et al. Trisubstituted-Imidazoles Induce Apoptosis in Human Breast Cancer Cells by Targeting the Oncogenic PI3K/Akt/mTOR Signaling Pathway. PLoS ONE 2016, 11, e0153155. [CrossRef] [PubMed]

33. Singh, S.S.; Yap, W.N.; Arfuso, F.; Kar, S.; Wang, C.; Cai, W.; Dharmarajan, A.M.; Sethi, G.; Kumar, A.P. Targeting the PI3K/Akt signaling pathway in gastric carcinoma: A reality for personalized medicine? World J. Gastroenterol. 2015, 21, 12261-12273. [CrossRef] [PubMed]

34. Xiang, Y.; Li, J.P.; Guo, W.; Wang, D.Q.; Yao, A.; Zhang, H.M.; Huang, F.; Li, H.H.; Dai, Z.T.; Zhang, Z.J.; et al. Novel interactions between ER $\alpha-36$ and STAT3 mediate breast cancer cell migration. Cell Commun. Signal. 2019, 17, 93. [CrossRef] [PubMed]

35. Kannan, M.; Jayamohan, S.; Moorthy, R.K.; Chabattula, S.C.; Ganeshan, M.; Arockiam, A.J.V. AEG-1/miR-221 Axis Cooperatively Regulates the Progression of Hepatocellular Carcinoma by Targeting PTEN/PI3K/AKT Signaling Pathway. Int. J. Mol. Sci. 2019, 20, 5526. [CrossRef]

36. Ling, C.; Wang, X.; Zhu, J.; Tang, H.; Du, W.; Zeng, Y.; Sun, L.; Huang, J.A.; Liu, Z. MicroRNA-4286 promotes cell proliferation, migration, and invasion via PTEN regulation of the PI3K/Akt pathway in non-small cell lung cancer. Cancer Med. 2019, 8, 3520-3531. [CrossRef]

37. Pang, Y.; Wu, J.; Li, X.; Wang, C.; Wang, M.; Liu, J.; Yang, G. NEAT1/miR-124/STAT3 feedback loop promotes breast cancer progression. Int. J. Oncol. 2019, 55, 745-754. [CrossRef]

38. Siveen, K.S.; Ahn, K.S.; Ong, T.H.; Shanmugam, M.K.; Li, F.; Yap, W.N.; Kumar, A.P.; Fong, C.W.; Tergaonkar, V.; Hui, K.M.; et al. Y-tocotrienol inhibits angiogenesis-dependent growth of human hepatocellular carcinoma through abrogation of AKT/mTOR pathway in an orthotopic mouse model. Oncotarget 2014, 5, 1897-1911. [CrossRef]

39. Ko, J.H.; Nam, D.; Um, J.Y.; Jung, S.H.; Sethi, G.; Ahn, K.S. Bergamottin Suppresses Metastasis of Lung Cancer Cells through Abrogation of Diverse Oncogenic Signaling Cascades and Epithelial-to-Mesenchymal Transition. Molecules 2018, 23, 1601. [CrossRef]

40. Maehama, T.; Dixon, J.E. The tumor suppressor, PTEN/MMAC1, dephosphorylates the lipid second messenger, phosphatidylinositol 3, 4, 5-trisphosphate. J. Biol. Chem. 1998, 273, 13375-13378. [CrossRef]

41. Monisha, J.; Roy, N.K.; Padmavathi, G.; Banik, K.; Bordoloi, D.; Khwairakpam, A.D.; Arfuso, F.; Chinnathambi, A.; Alahmadi, T.A.; Alharbi, S.A.; et al. NGAL is Downregulated in Oral Squamous Cell Carcinoma and Leads to Increased Survival, Proliferation, Migration and Chemoresistance. Cancers 2018, 10, 228. [CrossRef] [PubMed]

42. Ong, P.S.; Wang, L.Z.; Dai, X.; Tseng, S.H.; Loo, S.J.; Sethi, G. Judicious Toggling of mTOR Activity to Combat Insulin Resistance and Cancer: Current Evidence and Perspectives. Front. Pharmacol. 2016, 7, 395. [CrossRef] [PubMed]

43. Song, M.S.; Salmena, L.; Pandolfi, P.P. The functions and regulation of the PTEN tumour suppressor. Nat. Rev. Mol. Cell Biol. 2012, 13, 283-296. [CrossRef]

44. Yang, M.H.; Lee, J.H.; Ko, J.H.; Jung, S.H.; Sethi, G.; Ahn, K.S. Brassinin Represses Invasive Potential of Lung Carcinoma Cells through Deactivation of PI3K/Akt/mTOR Signaling Cascade. Molecules 2019, 24, 1584. [CrossRef] [PubMed]

45. Lee, J.H.; Chinnathambi, A.; Alharbi, S.A.; Shair, O.H.M.; Sethi, G.; Ahn, K.S. Farnesol abrogates epithelial to mesenchymal transition process through regulating Akt/mTOR pathway. Pharmacol. Res. 2019, 150, 104504. [CrossRef]

46. Shen, W.H.; Balajee, A.S.; Wang, J.; Wu, H.; Eng, C.; Pandolfi, P.P.; Yin, Y. Essential role for nuclear PTEN in maintaining chromosomal integrity. Cell 2007, 128, 157-170. [CrossRef] [PubMed]

47. Lee, Y.-R.; Chen, M.; Pandolfi, P.P. The functions and regulation of the PTEN tumour suppressor: New modes and prospects. Nat. Rev. Mol. Cell Biol. 2018, 19, 547-562. [CrossRef] [PubMed]

48. Khan, S.; Kumagai, T.; Vora, J.; Bose, N.; Sehgal, I.; Koeffler, P.H.; Bose, S. PTEN promoter is methylated in a proportion of invasive breast cancers. Int. J. Cancer 2004, 112, 407-410. [CrossRef]

49. Mirmohammadsadegh, A.; Marini, A.; Nambiar, S.; Hassan, M.; Tannapfel, A.; Ruzicka, T.; Hengge, U.R. Epigenetic silencing of the PTEN gene in melanoma. Cancer Res. 2006, 66, 6546-6552. [CrossRef] [PubMed] 
50. Salvesen, H.B.; MacDonald, N.; Ryan, A.; Jacobs, I.J.; Lynch, E.D.; Akslen, L.A.; Das, S. PTEN methylation is associated with advanced stage and microsatellite instability in endometrial carcinoma. Int. J. Cancer 2001, 91, 22-26. [CrossRef]

51. Soria, J.-C.; Lee, H.-Y.; Lee, J.I.; Wang, L.; Issa, J.-P.; Kemp, B.L.; Liu, D.D.; Kurie, J.M.; Mao, L.; Khuri, F.R. Lack of PTEN expression in non-small cell lung cancer could be related to promoter methylation. Clin. Cancer Res. 2002, 8, 1178-1184.

52. Zhang, J.; Lee, Y.-R.; Dang, F.; Gan, W.; Menon, A.V.; Katon, J.M.; Hsu, C.-H.; Asara, J.M.; Tibarewal, P.; Leslie, N.R. PTEN Methylation by NSD2 Controls Cellular Sensitivity to DNA Damage. Cancer Discov. 2019, 9, 1306-1323. [CrossRef] [PubMed]

53. Zhang, S.; Yu, D. PI (3) king apart PTEN's role in cancer. Clin. Cancer Res. 2010, 16, 4325-4330. [CrossRef] [PubMed]

54. Bazzichetto, C.; Conciatori, F.; Pallocca, M.; Falcone, I.; Fanciulli, M.; Cognetti, F.; Milella, M.; Ciuffreda, L. PTEN as a prognostic/predictive biomarker in cancer: An unfulfilled promise? Cancers 2019, 11, 435. [CrossRef] [PubMed]

55. Knudson, A.G. Mutation and cancer: Statistical study of retinoblastoma. Proc. Natl. Acad. Sci. USA 1971, 68, 820-823. [CrossRef] [PubMed]

56. Carracedo, A.; Alimonti, A.; Pandolfi, P.P. PTEN level in tumor suppression: How much is too little? Cancer Res. 2011, 71, 629-633. [CrossRef]

57. Trotman, L.C.; Niki, M.; Dotan, Z.A.; Koutcher, J.A.; Di Cristofano, A.; Xiao, A.; Khoo, A.S.; Roy-Burman, P.; Greenberg, N.M.; Van Dyke, T. Pten dose dictates cancer progression in the prostate. PLoS Biol. 2003, 1. [CrossRef]

58. Todorova, P.K.; Fletcher-Sananikone, E.; Mukherjee, B.; Kollipara, R.; Vemireddy, V.; Xie, X.J.; Guida, P.M.; Story, M.D.; Hatanpaa, K.; Habib, A.A.; et al. Radiation-Induced DNA Damage Cooperates with Heterozygosity of TP53 and PTEN to Generate High-Grade Gliomas. Cancer Res. 2019, 79, 3749-3761. [CrossRef]

59. Liu, X.; Zhang, P.; Xie, C.; Sham, K.W.Y.; Ng, S.S.M.; Chen, Y.; Cheng, C.H.K. Activation of PTEN by inhibition of TRPV4 suppresses colon cancer development. Cell Death Dis. 2019, 10, 460. [CrossRef]

60. Bowen, C.; Ostrowski, M.C.; Leone, G.; Gelmann, E.P. Loss of PTEN Accelerates NKX3.1 Degradation to Promote Prostate Cancer Progression. Cancer Res. 2019, 79, 4124-4134. [CrossRef]

61. Shanmugam, M.K.; Ahn, K.S.; Hsu, A.; Woo, C.C.; Yuan, Y.; Tan, K.H.B.; Chinnathambi, A.; Alahmadi, T.A.; Alharbi, S.A.; Koh, A.P.F.; et al. Thymoquinone Inhibits Bone Metastasis of Breast Cancer Cells Through Abrogation of the CXCR4 Signaling Axis. Front. Pharmacol. 2018, 9, 1294. [CrossRef] [PubMed]

62. Siveen, K.S.; Mustafa, N.; Li, F.; Kannaiyan, R.; Ahn, K.S.; Kumar, A.P.; Chng, W.J.; Sethi, G. Thymoquinone overcomes chemoresistance and enhances the anticancer effects of bortezomib through abrogation of NF-KB regulated gene products in multiple myeloma xenograft mouse model. Oncotarget 2014, 5, 634-648. [CrossRef] [PubMed]

63. Sawhney, M.; Rohatgi, N.; Kaur, J.; Shishodia, S.; Sethi, G.; Gupta, S.D.; Deo, S.V.; Shukla, N.K.; Aggarwal, B.B.; Ralhan, R. Expression of NF-kappaB parallels COX-2 expression in oral precancer and cancer: Association with smokeless tobacco. Int. J. Cancer 2007, 120, 2545-2556. [CrossRef]

64. Sethi, G.; Ahn, K.S.; Sung, B.; Aggarwal, B.B. Pinitol targets nuclear factor-kappaB activation pathway leading to inhibition of gene products associated with proliferation, apoptosis, invasion, and angiogenesis. Mol. Cancer Ther. 2008, 7, 1604-1614. [CrossRef] [PubMed]

65. Man, X.; Piao, C.; Lin, X.; Kong, C.; Cui, X.; Jiang, Y. USP13 functions as a tumor suppressor by blocking the NF-kB-mediated PTEN downregulation in human bladder cancer. J. Exp. Clin. Cancer Res. 2019, 38, 259. [CrossRef]

66. Zhu, Y.; Liu, B.; Zhang, P.; Zhang, J.; Wang, L. LncRNA TUSC8 inhibits the invasion and migration of cervical cancer cells via miR-641/PTEN axis. Cell Biol. Int. 2019, 43, 781-788. [CrossRef]

67. Ma, J.; Sun, X.; Wang, Y.; Chen, B.; Qian, L.; Wang, Y. Fibroblast-derived CXCL12 regulates PTEN expression and is associated with the proliferation and invasion of colon cancer cells via PI3k/Akt signaling. Cell Commun. Signal. 2019, 17, 119. [CrossRef]

68. Hamid, A.A.; Gray, K.P.; Huang, Y.; Bowden, M.; Pomerantz, M.; Loda, M.; Sweeney, C.J. Loss of PTEN Expression Detected by Fluorescence Immunohistochemistry Predicts Lethal Prostate Cancer in Men Treated with Prostatectomy. Eur. Urol. Oncol. 2019, 2, 475-482. [CrossRef] 
69. Li, G.; Guo, X.; Chen, M.; Tang, L.; Jiang, H.; Day, J.X.; Xie, Y.; Peng, L.; Xu, X.; Li, J.; et al. Prevalence and spectrum of AKT1, PIK3CA, PTEN and TP53 somatic mutations in Chinese breast cancer patients. PLoS ONE 2018, 13, e0203495. [CrossRef]

70. Rimawi, M.F.; De Angelis, C.; Contreras, A.; Pareja, F.; Geyer, F.C.; Burke, K.A.; Herrera, S.; Wang, T.; Mayer, I.A.; Forero, A.; et al. Low PTEN levels and PIK3CA mutations predict resistance to neoadjuvant lapatinib and trastuzumab without chemotherapy in patients with HER2 over-expressing breast cancer. Breast Cancer Res. Treat. 2018, 167, 731-740. [CrossRef]

71. Lin, P.C.; Lin, J.K.; Lin, H.H.; Lan, Y.T.; Lin, C.C.; Yang, S.H.; Chen, W.S.; Liang, W.Y.; Jiang, J.K.; Chang, S.C. A comprehensive analysis of phosphatase and tensin homolog deleted on chromosome 10 (PTEN) loss in colorectal cancer. World J. Surg. Oncol. 2015, 13, 186. [CrossRef] [PubMed]

72. Snietura, M.; Jaworska, M.; Mlynarczyk-Liszka, J.; Goraj-Zajac, A.; Piglowski, W.; Lange, D.; Wozniak, G.; Nowara, E.; Suwinski, R. PTEN as a prognostic and predictive marker in postoperative radiotherapy for squamous cell cancer of the head and neck. PLoS ONE 2012, 7, e33396. [CrossRef] [PubMed]

73. Stern, H.M.; Gardner, H.; Burzykowski, T.; Elatre, W.; O’Brien, C.; Lackner, M.R.; Pestano, G.A.; Santiago, A.; Villalobos, I.; Eiermann, W.; et al. PTEN Loss Is Associated with Worse Outcome in HER2-Amplified Breast Cancer Patients but Is Not Associated with Trastuzumab Resistance. Clin. Cancer Res. 2015, 21, 2065-2074. [CrossRef] [PubMed]

74. Wu, Y.; Sarkissyan, M.; Elshimali, Y.; Vadgama, J.V. Triple negative breast tumors in African-American and Hispanic/Latina women are high in CD44+, low in CD24+, and have loss of PTEN. PLoS ONE 2013, 8, e78259. [CrossRef] [PubMed]

75. Zu, K.; Martin, N.E.; Fiorentino, M.; Flavin, R.; Lis, R.T.; Sinnott, J.A.; Finn, S.; Penney, K.L.; Ma, J.; Fazli, L.; et al. Protein expression of PTEN, insulin-like growth factor I receptor (IGF-IR), and lethal prostate cancer: A prospective study. Cancer Epidemiol. Biomark. Prev. 2013, 22, 1984-1993. [CrossRef] [PubMed]

76. Taghavipour, M.; Sadoughi, F.; Mirzaei, H.; Yousefi, B.; Moazzami, B.; Chaichian, S.; Mansournia, M.A.; Asemi, Z. Apoptotic functions of microRNAs in pathogenesis, diagnosis, and treatment of endometriosis. Cell Biosci. 2020, 10, 12. [CrossRef]

77. Pourhanifeh, M.H.; Mahjoubin-Tehran, M.; Karimzadeh, M.R.; Mirzaei, H.R.; Razavi, Z.S.; Sahebkar, A.; Hosseini, N.; Mirzaei, H.; Hamblin, M.R. Autophagy in cancers including brain tumors: Role of MicroRNAs. Cell Commun. Signal. 2020, 18, 88. [CrossRef]

78. Yousefi, F.; Shabaninejad, Z.; Vakili, S.; Derakhshan, M.; Movahedpour, A.; Dabiri, H.; Ghasemi, Y.; Mahjoubin-Tehran, M.; Nikoozadeh, A.; Savardashtaki, A.; et al. TGF- $\beta$ and WNT signaling pathways in cardiac fibrosis: Non-coding RNAs come into focus. Cell Commun. Signal. 2020, 18, 87. [CrossRef]

79. Hallajzadeh, J.; Amirani, E.; Mirzaei, H.; Shafabakhsh, R.; Mirhashemi, S.M.; Sharifi, M.; Yousefi, B.; Mansournia, M.A.; Asemi, Z. Circular RNAs: New genetic tools in melanoma. Biomark. Med. 2020, $14,7$. [CrossRef]

80. Nahand, J.S.; Karimzadeh, M.R.; Nezamnia, M.; Fatemipour, M.; Khatami, A.; Jamshidi, S.; Moghoofei, M.; Taghizadieh, M.; Hajighadimi, S.; Shafiee, A.; et al. The role of miR-146a in viral infection. Iubmb Life 2020, 72, 343-360. [CrossRef]

81. Nahand, J.S.; Mahjoubin-Tehran, M.; Moghoofei, M.; Pourhanifeh, M.H.; Mirzaei, H.R.; Asemi, Z.; Khatami, A.; Bokharaei-Salim, F.; Mirzaei, H.; Hamblin, M.R. Exosomal miRNAs: Novel players in viral infection. Epigenomics 2020, 12, 353-370. [CrossRef] [PubMed]

82. Naeli, P.; Yousefi, F.; Ghasemi, Y.; Savardashtaki, A.; Mirzaei, H. The Role of MicroRNAs in Lung Cancer: Implications for Diagnosis and Therapy. Curr. Mol. Med. 2020, 20, 90-101. [CrossRef] [PubMed]

83. Javandoost, E.; Firoozi-Majd, E.; Rostamian, H.; Khakpoor- Koosheh, M.; Mirzaei, H.R. Role of microRNAs in Chronic Lymphocytic Leukemia Pathogenesis. Curr. Med. Chem. 2020, 27, 282-297. [CrossRef] [PubMed]

84. Rezaei, S.; Mahjoubin-Tehran, M.; Aghaee-Bakhtiari, S.H.; Jalili, A.; Movahedpour, A.; Khan, H.; Moghoofei, M.; Shojaei, Z.; Hamblin, M.R.; Mirzaei, H. Autophagy-related MicroRNAs in Chronic Lung Diseases and Lung Cancer. Crit. Rev. Oncol./Hematol. 2020. [CrossRef] [PubMed]

85. Jamali, Z.; Taheri-Anganeh, M.; Shabaninejad, Z.; Keshavarzi, A.; Taghizadeh, H.; Razavi, Z.S.; Mottaghi, R.; Abolhassan, M.; Movahedpour, A.; Mirzaei, H. Autophagy regulation by microRNAs: Novel insights into osteosarcoma therapy. Iubmb Life 2020, 72, 1306-1321. [CrossRef]

86. Varghese, E.; Liskova, A.; Kubatka, P.; Samuel, S.M.; Büsselberg, D. Anti-Angiogenic Effects of Phytochemicals on miRNA Regulating Breast Cancer Progression. Biomolecules 2020, 10, 191. [CrossRef] 
87. Ramírez-Moya, J.; Wert-Lamas, L.; Santisteban, P. MicroRNA-146b promotes PI3K/AKT pathway hyperactivation and thyroid cancer progression by targeting PTEN. Oncogene 2018, 37, 3369-3383. [CrossRef]

88. Jiang, J.H.; Lv, Q.Y.; Yi, Y.X.; Liao, J.; Wang, X.W.; Zhang, W. MicroRNA-200a promotes proliferation and invasion of ovarian cancer cells by targeting PTEN. Eur. Rev. Med. Pharmacol. Sci. 2018, 22, 6260-6267. [CrossRef]

89. He, T.; Sun, Y.; Zhang, Y.; Zhao, S.; Zheng, Y.; Hao, G.; Shi, Y. MicroRNA-200b and microRNA-200c are up-regulated in PCOS granulosa cell and inhibit KGN cell proliferation via targeting PTEN. Reprod. Biol. Endocrinol. 2019, 17, 68. [CrossRef]

90. Shi, J.; Han, Y.; Lin, D.; Wang, K.; Liu, B.; Gao, C. MicroRNA-19a promotes proliferative and migratory abilities of NSCLC cells by inhibiting PTEN expression. JBUON 2019, 24, 955-962.

91. Bao, L.; Li, X. MicroRNA-32 targeting PTEN enhances M2 macrophage polarization in the glioma microenvironment and further promotes the progression of glioma. Mol. Cell. Biochem. 2019, 460, 67-79. [CrossRef] [PubMed]

92. Cheng, J.-T.; Wang, L.; Wang, H.; Tang, F.-R.; Cai, W.-Q.; Sethi, G.; Xin, H.-W.; Ma, Z. Insights into Biological Role of LncRNAs in Epithelial-Mesenchymal Transition. Cells 2019, 8, 1178. [CrossRef] [PubMed]

93. Loh, C.-Y.; Chai, J.Y.; Tang, T.F.; Wong, W.F.; Sethi, G.; Shanmugam, M.K.; Chong, P.P.; Looi, C.Y. The E-Cadherin and N-Cadherin Switch in Epithelial-to-Mesenchymal Transition: Signaling, Therapeutic Implications, and Challenges. Cells 2019, 8, 1118. [CrossRef] [PubMed]

94. Mukherjee, A.; Madamsetty, V.S.; Paul, M.K.; Mukherjee, S. Recent Advancements of Nanomedicine towards Antiangiogenic Therapy in Cancer. Int. J. Mol. Sci. 2020, 21, 455. [CrossRef]

95. Hashemi Goradel, N.; Ghiyami-Hour, F.; Jahangiri, S.; Negahdari, B.; Sahebkar, A.; Masoudifar, A.; Mirzaei, H. Nanoparticles as new tools for inhibition of cancer angiogenesis. J. Cell. Physiol. 2018, 233, 2902-2910. [CrossRef]

96. Mashreghi, M.; Azarpara, H.; Bazaz, M.R.; Jafari, A.; Masoudifar, A.; Mirzaei, H.; Jaafari, M.R. Angiogenesis biomarkers and their targeting ligands as potential targets for tumor angiogenesis. J. Cell. Physiol. 2018, 233, 2949-2965. [CrossRef]

97. Zang, C.; Sun, J.; Liu, W.; Chu, C.; Jiang, L.; Ge, R. miRNA-21 promotes cell proliferation and invasion via VHL/PI3K/AKT in papillary thyroid carcinoma. Hum. Cell 2019, 32, 428-436. [CrossRef]

98. Samakova, A.; Gazova, A.; Sabova, N.; Valaskova, S.; Jurikova, M.; Kyselovic, J. The PI3k/Akt pathway is associated with angiogenesis, oxidative stress and survival of mesenchymal stem cells in pathophysiologic condition in ischemia. Physiol. Res. 2019, 68. [CrossRef]

99. Wu, Z.H.; Lin, C.; Liu, C.C.; Jiang, W.W.; Huang, M.Z.; Liu, X.; Guo, W.J. MiR-616-3p promotes angiogenesis and EMT in gastric cancer via the PTEN/AKT/mTOR pathway. Biochem. Biophys. Res. Commun. 2018, 501, 1068-1073. [CrossRef]

100. Yu, L.; Zhou, G.Q.; Li, D.C. MiR-136 triggers apoptosis in human gastric cancer cells by targeting AEG-1 and BCL2. Eur. Rev. Med. Pharmacol. Sci. 2018, 22, 7251-7256. [CrossRef]

101. Zheng, J.; Ge, P.; Liu, X.; Wei, J.; Wu, G.; Li, X. MiR-136 inhibits gastric cancer-specific peritoneal metastasis by targeting HOXC10. Tumour Biol. 2017, 39, 1010428317706207. [CrossRef] [PubMed]

102. Chen, X.; Huang, Z.; Chen, R. Microrna-136 promotes proliferation and invasion ingastric cancer cells through Pten/Akt/P-Akt signaling pathway. Oncol. Lett. 2018, 15, 4683-4689. [CrossRef]

103. Zhou, H.; Liu, H.; Jiang, M.; Zhang, S.; Chen, J.; Fan, X. Targeting MicroRNA-21 Suppresses Gastric Cancer Cell Proliferation and Migration via PTEN/Akt Signaling Axis. Cell Transplant. 2019, 28, 306-317. [CrossRef] [PubMed]

104. Yao, L.; Shi, W.; Gu, J. Micro-RNA 205-5p is Involved in the Progression of Gastric Cancer and Targets Phosphatase and Tensin Homolog (PTEN) in SGC-7901 Human Gastric Cancer Cells. Med. Sci. Monit. 2019, 25, 6367-6377. [CrossRef] [PubMed]

105. Yang, T.S.; Yang, X.H.; Wang, X.D.; Wang, Y.L.; Zhou, B.; Song, Z.S. MiR-214 regulate gastric cancer cell proliferation, migration and invasion by targeting PTEN. Cancer Cell Int. 2013, 13, 68. [CrossRef]

106. Li, L.; Zhu, X.; Shou, T.; Yang, L.; Cheng, X.; Wang, J.; Deng, L.; Zheng, Y. MicroRNA-28 promotes cell proliferation and invasion in gastric cancer via the PTEN/PI3K/AKT signalling pathway. Mol. Med. Rep. 2018, 17, 4003-4010. [CrossRef]

107. Wang, P.; Guan, Q.; Zhou, D.; Yu, Z.; Song, Y.; Qiu, W. miR-21 Inhibitors Modulate Biological Functions of Gastric Cancer Cells via PTEN/PI3K/mTOR Pathway. DNA Cell Biol. 2018, 37, 38-45. [CrossRef] 
108. Zhang, B.G.; Li, J.F.; Yu, B.Q.; Zhu, Z.G.; Liu, B.Y.; Yan, M. microRNA-21 promotes tumor proliferation and invasion in gastric cancer by targeting PTEN. Oncol. Rep. 2012, 27, 1019-1026. [CrossRef]

109. Ding, K.; Wu, Z.; Wang, N.; Wang, X.; Wang, Y.; Qian, P.; Meng, G.; Tan, S. MiR-26a performs converse roles in proliferation and metastasis of different gastric cancer cells via regulating of PTEN expression. Pathol. Res. Pract. 2017, 213, 467-475. [CrossRef]

110. Yang, T.S.; Yang, X.H.; Chen, X.; Wang, X.D.; Hua, J.; Zhou, D.L.; Zhou, B.; Song, Z.S. MicroRNA-106b in cancer-associated fibroblasts from gastric cancer promotes cell migration and invasion by targeting PTEN. Febs Lett. 2014, 588, 2162-2169. [CrossRef]

111. Xin, R.; Bai, F.; Feng, Y.; Jiu, M.; Liu, X.; Bai, F.; Nie, Y.; Fan, D. MicroRNA-214 promotes peritoneal metastasis through regulating PTEN negatively in gastric cancer. Clin. Res. Hepatol. Gastroenterol. 2016, 40, 748-754. [CrossRef]

112. Li, C.; Song, L.; Zhang, Z.; Bai, X.X.; Cui, M.F.; Ma, L.J. MicroRNA-21 promotes TGF- $\beta 1$-induced epithelial-mesenchymal transition in gastric cancer through up-regulating PTEN expression. Oncotarget 2016, 7, 66989-67003. [CrossRef] [PubMed]

113. Xiong, X.; Ren, H.Z.; Li, M.H.; Mei, J.H.; Wen, J.F.; Zheng, C.L. Down-regulated miRNA-214 induces a cell cycle G1 arrest in gastric cancer cells by up-regulating the PTEN protein. Pathol. Oncol. Res. 2011, 17, 931-937. [CrossRef] [PubMed]

114. Ma, F.; Zhang, J.; Zhong, L.; Wang, L.; Liu, Y.; Wang, Y.; Peng, L.; Guo, B. Upregulated microRNA-301a in breast cancer promotes tumor metastasis by targeting PTEN and activating Wnt/ $\beta$-catenin signaling. Gene 2014, 535, 191-197. [CrossRef] [PubMed]

115. Fine, B.; Hodakoski, C.; Koujak, S.; Su, T.; Saal, L.H.; Maurer, M.; Hopkins, B.; Keniry, M.; Sulis, M.L.; Mense, S. Activation of the PI3K pathway in cancer through inhibition of PTEN by exchange factor P-REX2a. Science 2009, 325, 1261-1265. [CrossRef] [PubMed]

116. Guo, B.; Liu, L.; Yao, J.; Ma, R.; Chang, D.; Li, Z.; Song, T.; Huang, C. miR-338-3p suppresses gastric cancer progression through a PTEN-AKT axis by targeting P-REX2a. Mol. Cancer Res. 2014, 12, 313-321. [CrossRef]

117. Zeng, Y.; Fu, M.; Wu, G.W.; Zhang, A.Z.; Chen, J.P.; Lin, H.Y.; Fu, Y.A.; Jia, J.; Cai, Z.D.; Wu, X.J.; et al. Upregulation of microRNA-370 promotes cell apoptosis and inhibits proliferation by targeting PTEN in human gastric cancer. Int. J. Oncol. 2016, 49, 1589-1599. [CrossRef]

118. Manu, K.A.; Shanmugam, M.K.; Ramachandran, L.; Li, F.; Siveen, K.S.; Chinnathambi, A.; Zayed, M.E.; Alharbi, S.A.; Arfuso, F.; Kumar, A.P.; et al. Isorhamnetin augments the anti-tumor effect of capecitabine through the negative regulation of NF-KB signaling cascade in gastric cancer. Cancer Lett. 2015, 363, 28-36. [CrossRef]

119. Manu, K.A.; Shanmugam, M.K.; Li, F.; Chen, L.; Siveen, K.S.; Ahn, K.S.; Kumar, A.P.; Sethi, G. Simvastatin sensitizes human gastric cancer xenograft in nude mice to capecitabine by suppressing nuclear factor-kappa B-regulated gene products. J. Mol. Med. 2014, 92, 267-276. [CrossRef]

120. Ramachandran, L.; Manu, K.A.; Shanmugam, M.K.; Li, F.; Siveen, K.S.; Vali, S.; Kapoor, S.; Abbasi, T.; Surana, R.; Smoot, D.T.; et al. Isorhamnetin inhibits proliferation and invasion and induces apoptosis through the modulation of peroxisome proliferator-activated receptor $\gamma$ activation pathway in gastric cancer. J. Biol. Chem. 2012, 287, 38028-38040. [CrossRef]

121. Hwang, S.T.; Kim, C.; Lee, J.H.; Chinnathambi, A.; Alharbi, S.A.; Shair, O.H.M.; Sethi, G.; Ahn, K.S. Cycloastragenol can negate constitutive STAT3 activation and promote paclitaxel-induced apoptosis in human gastric cancer cells. Phytomedicine 2019, 59, 152907. [CrossRef] [PubMed]

122. Manu, K.A.; Shanmugam, M.K.; Ramachandran, L.; Li, F.; Fong, C.W.; Kumar, A.P.; Tan, P.; Sethi, G. First evidence that $\gamma$-tocotrienol inhibits the growth of human gastric cancer and chemosensitizes it to capecitabine in a xenograft mouse model through the modulation of NF-kB pathway. Clin. Cancer Res. 2012, 18, 2220-2229. [CrossRef] [PubMed]

123. Zhao, Y.; Shen, X.; Zhu, Y.; Wang, A.; Xiong, Y.; Wang, L.; Fei, Y.; Wang, Y.; Wang, W.; Lin, F.; et al. Cathepsin L-mediated resistance of paclitaxel and cisplatin is mediated by distinct regulatory mechanisms. J. Exp. Clin. Cancer Res. 2019, 38, 333. [CrossRef] [PubMed]

124. Wang, S.; Tie, J.; Wang, R.; Hu, F.; Gao, L.; Wang, W.; Wang, L.; Li, Z.; Hu, S.; Tang, S.; et al. SOX2, a predictor of survival in gastric cancer, inhibits cell proliferation and metastasis by regulating PTEN. Cancer Lett. 2015, 358, 210-219. [CrossRef] [PubMed] 
125. Tan, L.M.; Li, X.; Qiu, C.F.; Zhu, T.; Hu, C.P.; Yin, J.Y.; Zhang, W.; Zhou, H.H.; Liu, Z.Q. CLEC4M is associated with poor prognosis and promotes cisplatin resistance in NSCLC patients. J. Cancer 2019, 10, 6374-6383. [CrossRef]

126. Hou, S.; Jin, W.; Xiao, W.; Deng, B.; Wu, D.; Zhi, J.; Wu, K.; Cao, X.; Chen, S.; Ding, Y.; et al. Integrin $\alpha 5$ promotes migration and cisplatin resistance in esophageal squamous cell carcinoma cells. Am. J. Cancer Res. 2019, 9, 2774-2788.

127. Yang, S.M.; Huang, C.; Li, X.F.; Yu, M.Z.; He, Y.; Li, J. miR-21 confers cisplatin resistance in gastric cancer cells by regulating PTEN. Toxicology 2013, 306, 162-168. [CrossRef]

128. Shen, J.; Niu, W.; Zhang, H.; Jun, M.; Zhang, H. Downregulation of MicroRNA-147 Inhibits Cell Proliferation and Increases the Chemosensitivity of Gastric Cancer Cells to 5-Fluorouracil by Directly Targeting PTEN. Oncol. Res. 2018, 26, 901-911. [CrossRef]

129. Ralph, S.J.; Nozuhur, S.; RA, A.L.; Rodríguez-Enríquez, S.; Moreno-Sánchez, R. Repurposing drugs as pro-oxidant redox modifiers to eliminate cancer stem cells and improve the treatment of advanced stage cancers. Med. Res. Rev. 2019, 39, 2397-2426. [CrossRef]

130. Tian, Y.; Guo, W. A Review of the Molecular Pathways Involved in Resistance to BRAF Inhibitors in Patients with Advanced-Stage Melanoma. Med. Sci. Monit. 2020, 26, e920957. [CrossRef]

131. Chen, J.; Zhou, C.; Li, J.; Xiang, X.; Zhang, L.; Deng, J.; Xiong, J. miR-21-5p confers doxorubicin resistance in gastric cancer cells by targeting PTEN and TIMP3. Int. J. Mol. Med. 2018, 41, 1855-1866. [CrossRef] [PubMed]

132. Jian, B.; Li, Z.; Xiao, D.; He, G.; Bai, L.; Yang, Q. Downregulation of microRNA-193-3p inhibits tumor proliferation migration and chemoresistance in human gastric cancer by regulating PTEN gene. Tumour Biol. 2016, 37, 8941-8949. [CrossRef] [PubMed]

133. Wang, F.; Li, T.; Zhang, B.; Li, H.; Wu, Q.; Yang, L.; Nie, Y.; Wu, K.; Shi, Y.; Fan, D. MicroRNA-19a/b regulates multidrug resistance in human gastric cancer cells by targeting PTEN. Biochem. Biophys. Res. Commun. 2013, 434, 688-694. [CrossRef]

134. Eto, K.; Iwatsuki, M.; Watanabe, M.; Ida, S.; Ishimoto, T.; Iwagami, S.; Baba, Y.; Sakamoto, Y.; Miyamoto, Y.; Yoshida, N.; et al. The microRNA-21/PTEN pathway regulates the sensitivity of HER2-positive gastric cancer cells to trastuzumab. Ann. Surg. Oncol. 2014, 21, 343-350. [CrossRef] [PubMed]

135. Fang, Y.; Shen, H.; Li, H.; Cao, Y.; Qin, R.; Long, L.; Zhu, X.; Xie, C.; Xu, W. miR-106a confers cisplatin resistance by regulating PTEN/Akt pathway in gastric cancer cells. Acta Biochim. Biophys. Sin. 2013, 45, 963-972. [CrossRef] [PubMed]

136. Kim, W.; Lee, S.; Seo, D.; Kim, D.; Kim, K.; Kim, E.; Kang, J.; Seong, K.M.; Youn, H.; Youn, B. Cellular Stress Responses in Radiotherapy. Cells 2019, 8, 1105. [CrossRef]

137. Nagaraju, G.P.; Zakka, K.M.; Landry, J.C.; Shaib, W.L.; Lesinski, G.B.; El-Rayes, B.F. Inhibition of HSP90 overcomes resistance to chemotherapy and radiotherapy in pancreatic cancer. Int. J. Cancer 2019, 145, 1529-1537. [CrossRef]

138. Chun-Zhi, Z.; Lei, H.; An-Ling, Z.; Yan-Chao, F.; Xiao, Y.; Guang-Xiu, W.; Zhi-Fan, J.; Pei-Yu, P.; Qing-Yu, Z.; Chun-Sheng, K. MicroRNA-221 and microRNA-222 regulate gastric carcinoma cell proliferation and radioresistance by targeting PTEN. BMC Cancer 2010, 10, 367. [CrossRef]

139. Yin, Y.; Long, J.; He, Q.; Li, Y.; Liao, Y.; He, P.; Zhu, W. Emerging roles of circRNA in formation and progression of cancer. J. Cancer 2019, 10, 5015-5021. [CrossRef]

140. Sanger, H.L.; Klotz, G.; Riesner, D.; Gross, H.J.; Kleinschmidt, A.K. Viroids are single-stranded covalently closed circular RNA molecules existing as highly base-paired rod-like structures. Proc. Natl. Acad. Sci. USA 1976, 73, 3852-3856. [CrossRef]

141. Cocquerelle, C.; Mascrez, B.; Hétuin, D.; Bailleul, B. Mis-splicing yields circular RNA molecules. FASEB J. 1993, 7, 155-160. [CrossRef] [PubMed]

142. Danan, M.; Schwartz, S.; Edelheit, S.; Sorek, R. Transcriptome-wide discovery of circular RNAs in Archaea. Nucleic Acids Res. 2012, 40, 3131-3142. [CrossRef] [PubMed]

143. Song, T.; Xu, A.; Zhang, Z.; Gao, F.; Zhao, L.; Chen, X.; Gao, J.; Kong, X. CircRNA hsa_circRNA_101996 increases cervical cancer proliferation and invasion through activating TPX2 expression by restraining miR-8075. J. Cell. Physiol. 2019, 234, 14296-14305. [CrossRef] [PubMed] 
144. Sang, Y.; Chen, B.; Song, X.; Li, Y.; Liang, Y.; Han, D.; Zhang, N.; Zhang, H.; Liu, Y.; Chen, T.; et al. circRNA_0025202 Regulates Tamoxifen Sensitivity and Tumor Progression via Regulating the miR-182-5p/FOXO3a Axis in Breast Cancer. Mol. Ther. 2019, 27, 1638-1652. [CrossRef]

145. Yang, C.Y.; Zhang, F.X.; He, J.N.; Wang, S.Q. CircRNA_100876 promote proliferation and metastasis of breast cancer cells through adsorbing microRNA-361-3p in a sponge form. Eur. Rev. Med. Pharmacol. Sci. 2019, 23, 6962-6970. [CrossRef]

146. Ju, H.Q.; Zhao, Q.; Wang, F.; Lan, P.; Wang, Z.; Zuo, Z.X.; Wu, Q.N.; Fan, X.J.; Mo, H.Y.; Chen, L.; et al. A circRNA signature predicts postoperative recurrence in stage II/III colon cancer. Embo Mol. Med. 2019, 11, e10168. [CrossRef]

147. Yang, C.; Yuan, W.; Yang, X.; Li, P.; Wang, J.; Han, J.; Tao, J.; Li, P.; Yang, H.; Lv, Q.; et al. Circular RNA circ-ITCH inhibits bladder cancer progression by sponging miR-17/miR-224 and regulating p21, PTEN expression. Mol. Cancer 2018, 17, 19. [CrossRef]

148. Li, X.; Sun, X.H.; Xu, H.Y.; Pan, H.S.; Liu, Y.; He, L. Circ_ORC2 enhances the regulatory effect of miR-19a on its target gene PTEN to affect osteosarcoma cell growth. Biochem. Biophys. Res. Commun. 2019, 514, 1172-1178. [CrossRef]

149. Ren, C.; Liu, J.; Zheng, B.; Yan, P.; Sun, Y.; Yue, B. The circular RNA circ-ITCH acts as a tumour suppressor in osteosarcoma via regulating miR-22. Artif. Cells Nanomed. Biotechnol. 2019, 47, 3359-3367. [CrossRef]

150. Zhang, H.; Wang, X.; Hu, B.; Zhang, F.; Wei, H.; Li, L. Circular RNA ZFR accelerates non-small cell lung cancer progression by acting as a miR-101-3p sponge to enhance CUL4B expression. Artif. Cells Nanomed. Biotechnol. 2019, 47, 3410-3416. [CrossRef]

151. Liu, T.; Liu, S.; Xu, Y.; Shu, R.; Wang, F.; Chen, C.; Zeng, Y.; Luo, H. Circular RNA-ZFR Inhibited Cell Proliferation and Promoted Apoptosis in Gastric Cancer by Sponging miR-130a/miR-107 and Modulating PTEN. Cancer Res. Treat. 2018, 50, 1396-1417. [CrossRef] [PubMed]

152. Li, R.C.; Ke, S.; Meng, F.K.; Lu, J.; Zou, X.J.; He, Z.G.; Wang, W.F.; Fang, M.H. CiRS-7 promotes growth and metastasis of esophageal squamous cell carcinoma via regulation of miR-7/HOXB13. Cell Death Dis. 2018, 9, 838. [CrossRef] [PubMed]

153. Sang, M.; Meng, L.; Liu, S.; Ding, P.; Chang, S.; Ju, Y.; Liu, F.; Gu, L.; Lian, Y.; Geng, C. Circular RNA ciRS-7 Maintains Metastatic Phenotypes as a ceRNA of miR-1299 to Target MMPs. Mol. Cancer Res. 2018, 16, 1665-1675. [CrossRef]

154. Pan, H.; Li, T.; Jiang, Y.; Pan, C.; Ding, Y.; Huang, Z.; Yu, H.; Kong, D. Overexpression of Circular RNA ciRS-7 Abrogates the Tumor Suppressive Effect of miR-7 on Gastric Cancer via PTEN/PI3K/AKT Signaling Pathway. J. Cell. Biochem. 2018, 119, 440-446. [CrossRef] [PubMed]

155. Zhang, J.; Liu, H.; Hou, L.; Wang, G.; Zhang, R.; Huang, Y.; Chen, X.; Zhu, J. Circular RNA_LARP4 inhibits cell proliferation and invasion of gastric cancer by sponging miR-424-5p and regulating LATS1 expression. Mol. Cancer 2017, 16, 151. [CrossRef] [PubMed]

156. Zou, T.; Wang, P.L.; Gao, Y.; Liang, W.T. Circular RNA_LARP4 is lower expressed and serves as a potential biomarker of ovarian cancer prognosis. Eur. Rev. Med. Pharmacol. Sci. 2018, 22, 7178-7182. [CrossRef]

157. Lin, W.; Ye, H.; You, K.; Chen, L. Up-regulation of circ_LARP4 suppresses cell proliferation and migration in ovarian cancer by regulating miR-513b-5p/LARP4 axis. Cancer Cell Int. 2020, 20, 5. [CrossRef]

158. Chen, Z.; Yao, N.; Gu, H.; Song, Y.; Ye, Z.; Li, L.; Lu, P.; Shao, Q. Circular RNA_LARP4 Sponges miR-1323 and Hampers Progression of Esophageal Squamous Cell Carcinoma Through Modulating PTEN/PI3K/AKT Pathway. Dig. Dis. Sci. 2020. [CrossRef]

159. Dai, X.; Guo, X.; Liu, J.; Cheng, A.; Peng, X.; Zha, L.; Wang, Z. Circular RNA circGRAMD1B inhibits gastric cancer progression by sponging miR-130a-3p and regulating PTEN and p21 expression. Aging 2019, 11, 9689-9708. [CrossRef]

160. Vafadar, A.; Shabaninejad, Z.; Movahedpour, A.; Mohammadi, S.; Fathullahzadeh, S.; Mirzaei, H.R.; Namdar, A.; Savardashtaki, A.; Mirzaei, H. Long Non-Coding RNAs As Epigenetic Regulators in Cancer. Curr. Pharm. Des. 2019, 25, 3563-3577. [CrossRef]

161. Pal, S.; Garg, M.; Pandey, A.K. Deciphering the Mounting Complexity of the p53 Regulatory Network in Correlation to Long Non-Coding RNAs (lncRNAs) in Ovarian Cancer. Cells 2020, 9, 527. [CrossRef] [PubMed] 
162. Kansara, S.; Pandey, V.; Lobie, P.E.; Sethi, G.; Garg, M.; Pandey, A.K. Mechanistic Involvement of Long Non-Coding RNAs in Oncotherapeutics Resistance in Triple-Negative Breast Cancer. Cells 2020, 9, 1511. [CrossRef] [PubMed]

163. Wang, J.; Xu, W.; He, Y.; Xia, Q.; Liu, S. LncRNA MEG3 impacts proliferation, invasion, and migration of ovarian cancer cells through regulating PTEN. Inflamm. Res. 2018, 67, 927-936. [CrossRef] [PubMed]

164. Dai, Y.; Wan, Y.; Qiu, M.; Wang, S.; Pan, C.; Wang, Y.; Ou, J. lncRNA MEG3 Suppresses the Tumorigenesis of Hemangioma by Sponging miR-494 and Regulating PTEN/ PI3K/AKT Pathway. Cell. Physiol. Biochem. Int. J. Exp. Cell. Physiol. Biochem. Pharmacol. 2018, 51, 2872-2886. [CrossRef]

165. Zhang, R.; Guo, Y.; Ma, Z.; Ma, G.; Xue, Q.; Li, F.; Liu, L. Long non-coding RNA PTENP1 functions as a ceRNA to modulate PTEN level by decoying miR-106b and miR-93 in gastric cancer. Oncotarget 2017, 8, 26079-26089. [CrossRef]

166. Chi, Y.; Wang, F.; Zhang, T.; Xu, H.; Zhang, Y.; Shan, Z.; Wu, S.; Fan, Q.; Sun, Y. miR-516a-3p inhibits breast cancer cell growth and EMT by blocking the Pygo2/Wnt signalling pathway. J. Cell. Mol. Med. 2019, 23, 6295-6307. [CrossRef]

167. Jiang, X.; Zhang, Z.; Song, C.; Deng, H.; Yang, R.; Zhou, L.; Sun, Y.; Zhang, Q. Glaucocalyxin A reverses EMT and TGF- $\beta 1$-induced EMT by inhibiting TGF- $\beta 1 / \operatorname{Smad} 2 / 3$ signaling pathway in osteosarcoma. Chem. Biol. Interact. 2019, 307, 158-166. [CrossRef]

168. Li, Y.; Shen, Z.; Wang, B.; Ye, C.; Lai, Z.; Jiang, H.; Wang, Z.; Jiang, K.; Ye, Y.; Wang, S. Long non-coding RNA GPR65-1 is up-regulated in gastric cancer and promotes tumor growth through the PTEN-AKT-slug signaling pathway. Cell Cycle 2018, 17, 759-765. [CrossRef]

169. Chen, P.; Zhao, X.; Wang, H.; Zheng, M.; Wang, Q.; Chang, W. The Down-Regulation of lncRNA PCAT18 Promotes the Progression of Gastric Cancer via MiR-107/PTEN/PI3K/AKT Signaling Pathway. Oncotargets Ther. 2019, 12, 11017-11031. [CrossRef]

170. Guo, J.; Li, Y.; Duan, H.; Yuan, L. LncRNA TUBA4B functions as a competitive endogenous RNA to inhibit gastric cancer progression by elevating PTEN via sponging miR-214 and miR-216a/b. Cancer Cell Int. 2019, 19, 156. [CrossRef]

171. Xu, Y.; Zhang, G.; Zou, C.; Gong, Z.; Wang, S.; Liu, J.; Ma, G.; Liu, X.; Zhang, W.; Jiang, P. Long noncoding RNA DGCR5 suppresses gastric cancer progression by acting as a competing endogenous RNA of PTEN and BTG1. J. Cell. Physiol. 2019, 234, 11999-12010. [CrossRef] [PubMed]

172. Yan, J.; Huang, X.; Zhang, X.; Chen, Z.; Ye, C.; Xiang, W.; Huang, Z. LncRNA LINC00470 promotes the degradation of PTEN mRNA to facilitate malignant behavior in gastric cancer cells. Biochem. Biophys. Res. Commun. 2020, 521, 887-893. [CrossRef] [PubMed]

173. Guo, J.Q.; Li, S.J.; Guo, G.X. Long Noncoding RNA AFAP1-AS1 Promotes Cell Proliferation and Apoptosis of Gastric Cancer Cells via PTEN/p-AKT Pathway. Dig. Dis. Sci. 2017, 62, 2004-2010. [CrossRef] [PubMed]

174. Lu, R.; Zhao, G.; Yang, Y.; Jiang, Z.; Cai, J.; Zhang, Z.; Hu, H. Long noncoding RNA HOTAIRM1 inhibits cell progression by regulating miR-17-5p/ PTEN axis in gastric cancer. J. Cell. Biochem. 2019, 120, 4952-4965. [CrossRef] [PubMed]

175. Xia, T.; Chen, S.; Jiang, Z.; Shao, Y.; Jiang, X.; Li, P.; Xiao, B.; Guo, J. Long noncoding RNA FER1L4 suppresses cancer cell growth by acting as a competing endogenous RNA and regulating PTEN expression. Sci. Rep. 2015, 5, 13445. [CrossRef]

176. Li, H.; Ma, X.; Yang, D.; Suo, Z.; Dai, R.; Liu, C. PCAT-1 contributes to cisplatin resistance in gastric cancer through epigenetically silencing PTEN via recruiting EZH2. J. Cell. Biochem. 2020, 121, 1353-1361. [CrossRef] [PubMed]

177. Wang, Z.; Liu, F.; Liao, W.; Yu, L.; Hu, Z.; Li, M.; Xia, H. Curcumin suppress glioblastoma cell proliferation by $\mathrm{p}-\mathrm{AKT} / \mathrm{mTOR}$ pathway and increased the PTEN expression. Arch. Biochem. Biophys. 2020. [CrossRef] [PubMed]

178. Chen, S.; Yang, S.; Wang, M.; Chen, J.; Huang, S.; Wei, Z.; Cheng, Z.; Wang, H.; Long, M.; Li, P. Curcumin inhibits zearalenone-induced apoptosis and oxidative stress in Leydig cells via modulation of the PTEN/Nrf2/Bip signaling pathway. Food Chem. Toxicol. 2020, 141, 111385. [CrossRef] [PubMed]

179. Tewari, D.; Nabavi, S.F.; Nabavi, S.M.; Sureda, A.; Farooqi, A.A.; Atanasov, A.G.; Vacca, R.A.; Sethi, G.; Bishayee, A. Targeting activator protein 1 signaling pathway by bioactive natural agents: Possible therapeutic strategy for cancer prevention and intervention. Pharmacol. Res. 2018, 128, 366-375. [CrossRef] [PubMed] 
180. Shanmugam, M.K.; Warrier, S.; Kumar, A.P.; Sethi, G.; Arfuso, F. Potential Role of Natural Compounds as Anti-Angiogenic Agents in Cancer. Curr. Vasc. Pharmacol. 2017, 15, 503-519. [CrossRef] [PubMed]

181. Deng, S.; Shanmugam, M.K.; Kumar, A.P.; Yap, C.T.; Sethi, G.; Bishayee, A. Targeting autophagy using natural compounds for cancer prevention and therapy. Cancer 2019, 125, 1228-1246. [CrossRef] [PubMed]

182. Li, Y.; Tian, L.; Sun, D.; Yin, D. Curcumin ameliorates atherosclerosis through upregulation of miR-126. J. Cell. Physiol. 2019, 234, 21049-21059. [CrossRef] [PubMed]

183. Ghelani, H.; Razmovski-Naumovski, V.; Chang, D.; Nammi, S. Chronic treatment of curcumin improves hepatic lipid metabolism and alleviates the renal damage in adenine-induced chronic kidney disease in Sprague-Dawley rats. BMC Nephrol. 2019, 20, 431. [CrossRef] [PubMed]

184. Pivari, F.; Mingione, A.; Brasacchio, C.; Soldati, L. Curcumin and Type 2 Diabetes Mellitus: Prevention and Treatment. Nutrients 2019, 11, 1837. [CrossRef]

185. Biswas, S.; Chen, S.; Liang, G.; Feng, B.; Cai, L.; Khan, Z.A.; Chakrabarti, S. Curcumin Analogs Reduce Stress and Inflammation Indices in Experimental Models of Diabetes. Front. Endocrinol. 2019, 10, 887. [CrossRef]

186. Giordano, A.; Tommonaro, G. Curcumin and Cancer. Nutrients 2019, 11, 2376. [CrossRef]

187. Ba, P.; Xu, M.; Yu, M.; Li, L.; Duan, X.; Lv, S.; Fu, G.; Yang, J.; Yang, P.; Yang, C.; et al. Curcumin suppresses the proliferation and tumorigenicity of Cal27 by modulating cancer associated fibroblasts of TSCC. Oral Dis. 2020. [CrossRef]

188. Qiang, Z.; Meng, L.; Yi, C.; Yu, L.; Chen, W.; Sha, W. Curcumin regulates the miR-21/PTEN/Akt pathway and acts in synergy with PD98059 to induce apoptosis of human gastric cancer MGC-803 cells. J. Int. Med. Res. 2019, 47, 1288-1297. [CrossRef]

189. Lee, J.H.; Kim, C.; Sethi, G.; Ahn, K.S. Brassinin inhibits STAT3 signaling pathway through modulation of PIAS-3 and SOCS-3 expression and sensitizes human lung cancer xenograft in nude mice to paclitaxel. Oncotarget 2015, 6, 6386-6405. [CrossRef]

190. Ko, J.-H.; Sethi, G.; Um, J.-Y.; Shanmugam, M.K.; Arfuso, F.; Kumar, A.P.; Bishayee, A.; Ahn, K.S. The Role of Resveratrol in Cancer Therapy. Int. J. Mol. Sci. 2017, 18, 2589. [CrossRef]

191. Amiri, A.; Asemi, Z.; Shafiee, A.; Hajighadimi, S.; Moradizarmehri, S.; Mirzaei, H.R.; Mirzaei, H. Role of resveratrol in modulating microRNAs in human diseases: From cancer to inflammatory disorder. Curr. Med. Chem. 2020. [CrossRef] [PubMed]

192. Geng, W.; Guo, X.; Zhang, L.; Ma, Y.; Wang, L.; Liu, Z.; Ji, H.; Xiong, Y. Resveratrol inhibits proliferation, migration and invasion of multiple myeloma cells via NEAT1-mediated Wnt/ $\beta$-catenin signaling pathway. Biomed. Pharmacother. 2018, 107, 484-494. [CrossRef]

193. Wu, F.; Cui, L. Resveratrol suppresses melanoma by inhibiting NF-kB/miR-221 and inducing TFG expression. Arch. Dermatol. Res. 2017, 309, 823-831. [CrossRef] [PubMed]

194. Karimi Dermani, F.; Saidijam, M.; Amini, R.; Mahdavinezhad, A.; Heydari, K.; Najafi, R. Resveratrol Inhibits Proliferation, Invasion, and Epithelial-Mesenchymal Transition by Increasing miR-200c Expression in HCT-116 Colorectal Cancer Cells. J. Cell. Biochem. 2017, 118, 1547-1555. [CrossRef] [PubMed]

195. Jing, X.; Cheng, W.; Wang, S.; Li, P.; He, L. Resveratrol induces cell cycle arrest in human gastric cancer MGC803 cells via the PTEN-regulated PI3K/Akt signaling pathway. Oncol. Rep. 2016, 35, 472-478. [CrossRef] [PubMed]

196. Lee, J.H.; Mohan, C.D.; Deivasigamani, A.; Jung, Y.Y.; Rangappa, S.; Basappa, S.; Chinnathambi, A.; Alahmadi, T.A.; Alharbi, S.A.; Garg, M.; et al. Brusatol suppresses STAT3-driven metastasis by downregulating epithelial-mesenchymal transition in hepatocellular carcinoma. J. Adv. Res. 2020. [CrossRef]

197. Ko, J.-H.; Yang, M.H.; Baek, S.H.; Nam, D.; Jung, S.H.; Ahn, K.S. Theacrine attenuates epithelial mesenchymal transition in human breast cancer MDA-MB-231 cells. Phytother. Res. 2019, 33, 1934-1942. [CrossRef]

198. Guo, Q.; Jing, F.J.; Xu, W.; Li, X.; Li, X.; Sun, J.L.; Xing, X.M.; Zhou, C.K.; Jing, F.B. Ubenimex induces autophagy inhibition and EMT suppression to overcome cisplatin resistance in GC cells by perturbing the CD13/EMP3/PI3K/AKT/NF-кB axis. Aging 2019, 12, 80-105. [CrossRef]

199. Yu, J.L.; Gao, X. MicroRNA 1301 inhibits cisplatin resistance in human ovarian cancer cells by regulating EMT and autophagy. Eur. Rev. Med. Pharmacol. Sci. 2020, 24, 1688-1696. [CrossRef]

200. Xu, J.; Liu, D.; Niu, H.; Zhu, G.; Xu, Y.; Ye, D.; Li, J.; Zhang, Q. Resveratrol reverses Doxorubicin resistance by inhibiting epithelial-mesenchymal transition (EMT) through modulating PTEN/Akt signaling pathway in gastric cancer. J. Exp. Clin. Cancer Res. 2017, 36, 19. [CrossRef] 
201. Ma, J.; Hu, X.; Li, J.; Wu, D.; Lan, Q.; Wang, Q.; Tian, S.; Dong, W. Enhancing conventional chemotherapy drug cisplatin-induced anti-tumor effects on human gastric cancer cells both in vitro and in vivo by Thymoquinone targeting PTEN gene. Oncotarget 2017, 8, 85926-85939. [CrossRef] [PubMed]

202. Qin, Y.; Li, L.; Chen, J.; Tang, X.; Liao, C.; Xie, Y.; Xiao, Q. Fentanyl inhibits progression of human gastric cancer MGC-803 cells by NF-kB downregulation and PTEN upregulation in vitro. Oncol. Res. Featur. Preclin. Clin. Cancer Ther. 2012, 20, 61-69. [CrossRef]

203. Pan, L.; Matloob, A.F.; Du, J.; Pan, H.; Dong, Z.; Zhao, J.; Feng, Y.; Zhong, Y.; Huang, B.; Lu, J. Vitamin D stimulates apoptosis in gastric cancer cells in synergy with trichostatin $\mathrm{A} /$ sodium butyrate-induced and 5-aza-2'-deoxycytidine-induced PTEN upregulation. Febs J. 2010, 277, 989-999. [CrossRef]

204. Bai, Z.; Zhang, Z.; Ye, Y.; Wang, S. Sodium butyrate induces differentiation of gastric cancer cells to intestinal cells via the PTEN/phosphoinositide 3-kinase pathway. Cell Biol. Int. 2010, 34, 1141-1145. [CrossRef] [PubMed]

205. Sun, J.; Piao, J.; Li, N.; Yang, Y.; Kim, K.Y.; Lin, Z. Valproic acid targets HDAC1/2 and HDAC1/PTEN/Akt signalling to inhibit cell proliferation via the induction of autophagy in gastric cancer. FEBS J. 2020, 287, 2118-2133. [CrossRef] [PubMed]

206. Sun, M.Y.; Sun, J.; Tao, J.; Yuan, Y.X.; Ni, Z.H.; Tang, Q.F. Zuo Jin Wan Reverses DDP Resistance in Gastric Cancer through ROCK/PTEN/PI3K Signaling Pathway. Evid. Based Complement. Altern. Med. 2018, 2018, 4278568. [CrossRef]

207. He, J.Q.; Zhang, S.R.; Li, D.F.; Tang, J.Y.; Wang, Y.Q.; He, X.; Li, Y.M.; Wu, H.; Zhou, M.; Jiao, J.; et al. Experimental Study on the Effect of a Weifufang on Human Gastric Adenocarcinoma Cell Line BGC-823 Xenografts and PTEN Gene Expression in Nude Mice. Cancer Biother. Radiopharm. 2020, 35, 199-207. [CrossRef]

208. Wang, S.Q.; Wang, C.; Chang, L.M.; Zhou, K.R.; Wang, J.W.; Ke, Y.; Yang, D.X.; Shi, H.G.; Wang, R.; Shi, X.L.; et al. Geridonin and paclitaxel act synergistically to inhibit the proliferation of gastric cancer cells through ROS-mediated regulation of the PTEN/PI3K/Akt pathway. Oncotarget 2016, 7, 72990-73002. [CrossRef]

209. Li, R.; Wang, X.; Zhang, X.H.; Chen, H.H.; Liu, Y.D. Ursolic acid promotes apoptosis of SGC-7901 gastric cancer cells through ROCK/PTEN mediated mitochondrial translocation of cofilin-1. Asian Pac. J. Cancer Prev. 2014, 15, 9593-9597. [CrossRef]

210. Chen, F.; Zhuang, M.; Zhong, C.; Peng, J.; Wang, X.; Li, J.; Chen, Z.; Huang, Y. Baicalein reverses hypoxia-induced 5-FU resistance in gastric cancer AGS cells through suppression of glycolysis and the PTEN/Akt/HIF-1 $\alpha$ signaling pathway. Oncol. Rep. 2015, 33, 457-463. [CrossRef]

211. Liu, Y.-L.; Zhang, G.-Q.; Yang, Y.; Zhang, C.-Y.; Fu, R.-X.; Yang, Y.-M. Genistein induces G2/M arrest in gastric cancer cells by increasing the tumor suppressor PTEN expression. Nutr. Cancer 2013, 65, 1034-1041. [CrossRef] [PubMed]

212. Liu, H.; Song, J.; Zhou, Y.; Cao, L.; Gong, Y.; Wei, Y.; Yang, H.; Tang, L. Methylxanthine derivatives promote autophagy in gastric cancer cells targeting PTEN. Anti Cancer Drugs 2019, 30, 347-355. [CrossRef] [PubMed]

213. Jeyamani, L.; Jayarajan, J.; Leelakrishnan, V.; Swaminathan, M. CagA and VacA genes of Helicobacter pylori and their clinical relevance. Indian J. Pathol. Microbiol. 2018, 61, 66-69. [CrossRef] [PubMed]

214. Weel, J.F.; van der Hulst, R.W.; Gerrits, Y.; Roorda, P.; Feller, M.; Dankert, J.; Tytgat, G.N.; van der Ende, A. The interrelationship between cytotoxin-associated gene A, vacuolating cytotoxin, and Helicobacter pylori-related diseases. J. Infect. Dis. 1996, 173, 1171-1175. [CrossRef] [PubMed]

215. Zhang, B.; Zhang, X.; Jin, M.; Hu, L.; Zang, M.; Qiu, W.; Wang, S.; Liu, B.; Liu, S.; Guo, D. CagA increases DNA methylation and decreases PTEN expression in human gastric cancer. Mol. Med. Rep. 2019, 19, 309-319. [CrossRef]

216. McDaniel, L.D.; Conkrite, K.L.; Chang, X.; Capasso, M.; Vaksman, Z.; Oldridge, D.A.; Zachariou, A.; Horn, M.; Diamond, M.; Hou, C.; et al. Common variants upstream of MLF1 at 3q25 and within CPZ at 4p16 associated with neuroblastoma. PLoS Genet. 2017, 13, e1006787. [CrossRef]

217. Perez, Y.; Menascu, S.; Cohen, I.; Kadir, R.; Basha, O.; Shorer, Z.; Romi, H.; Meiri, G.; Rabinski, T.; Ofir, R.; et al. RSRC1 mutation affects intellect and behaviour through aberrant splicing and transcription, downregulating IGFBP3. Brain 2018, 141, 961-970. [CrossRef]

218. Yu, S.; Gautam, N.; Quan, M.; Gao, Y. RSRC1 suppresses gastric cancer cell proliferation and migration by regulating PTEN expression. Mol. Med. Rep. 2019, 20, 1747-1753. [CrossRef] 
219. Zhao, C.; Tao, T.; Yang, L.; Qin, Q.; Wang, Y.; Liu, H.; Song, R.; Yang, X.; Wang, Q.; Gu, S.; et al. Loss of PDZK1 expression activates PI3K/AKT signaling via PTEN phosphorylation in gastric cancer. Cancer Lett. 2019, 453, 107-121. [CrossRef]

220. Zhang, R.; Zhang, J.; Luo, W.; Luo, Z.; Shi, S. WWP2 Is One Promising Novel Oncogene. Pathol. Oncol. Res. 2019, 25, 443-446. [CrossRef]

221. Chen, A.; Gao, B.; Zhang, J.; McEwen, T.; Shui, Q.Y.; Zhang, D.; Fang, D. The HECT-type E3 ubiquitin ligase AIP2 inhibits activation-induced T-cell death by catalyzing EGR2 ubiquitination. Mol. Cell. Biol. 2009, 29, 5348-5356. [CrossRef] [PubMed]

222. Li, H.; Zhang, Z.; Wang, B.; Zhang, J.; Zhao, Y.; Jin, Y. Wwp2-mediated ubiquitination of the RNA polymerase II large subunit in mouse embryonic pluripotent stem cells. Mol. Cell. Biol. 2007, 27, 5296-5305. [CrossRef] [PubMed]

223. Zou, W.; Chen, X.; Shim, J.-H.; Huang, Z.; Brady, N.; Hu, D.; Drapp, R.; Sigrist, K.; Glimcher, L.H.; Jones, D. The E3 ubiquitin ligase Wwp2 regulates craniofacial development through mono-ubiquitylation of Goosecoid. Nat. Cell Biol. 2011, 13, 59-65. [CrossRef] [PubMed]

224. Maddika, S.; Kavela, S.; Rani, N.; Palicharla, V.R.; Pokorny, J.L.; Sarkaria, J.N.; Chen, J. WWP2 is an E3 ubiquitin ligase for PTEN. Nat. Cell Biol. 2011, 13, 728-733. [CrossRef] [PubMed]

225. Li, H.; Zhang, P.; Zhang, Q.; Li, C.; Zou, W.; Chang, Z.; Cui, C.-P.; Zhang, L. WWP2 is a physiological ubiquitin ligase for phosphatase and tensin homolog (PTEN) in mice. J. Biol. Chem. 2018, 293, 8886-8899. [CrossRef]

226. Wang, Q.; Feng, Y.; Peng, W.; Ji, D.; Zhang, Z.; Qian, W.; Li, J.; Gu, Q.; Zhang, D.; Tang, J. Long noncoding RNA Linc02023 regulates PTEN stability and suppresses tumorigenesis of colorectal cancer in a PTEN-dependent pathway. Cancer Lett. 2019, 451, 68-78. [CrossRef]

227. Fukumoto, C.; Nakashima, D.; Kasamatsu, A.; Unozawa, M.; Shida-Sakazume, T.; Higo, M.; Ogawara, K.; Yokoe, H.; Shiiba, M.; Tanzawa, H. WWP2 is overexpressed in human oral cancer, determining tumor size and poor prognosis in patients: Downregulation of WWP2 inhibits the AKT signaling and tumor growth in mice. Oncoscience 2014, 1, 807. [CrossRef]

228. Yang, R.; He, Y.; Chen, S.; Lu, X.; Huang, C.; Zhang, G. Elevated expression of WWP2 in human lung adenocarcinoma and its effect on migration and invasion. Biochem. Biophys. Res. Commun. 2016, 479, 146-151. [CrossRef]

229. Wang, K.; Liu, J.; Zhao, X.; Li, H.; Luo, G.; Yu, Y.; Guo, Y.; Zhang, L.; Zhu, J.; Wang, S.; et al. WWP2 regulates proliferation of gastric cancer cells in a PTEN-dependent manner. Biochem. Biophys. Res. Commun. 2020, 521, 652-659. [CrossRef]

230. McConnell, B.B.; Yang, V.W. Mammalian Krüppel-like factors in health and diseases. Physiol. Rev. 2010, 90, 1337-1381. [CrossRef]

231. Yamanaka, S. Strategies and new developments in the generation of patient-specific pluripotent stem cells. Cell Stem Cell 2007, 1, 39-49. [CrossRef] [PubMed]

232. Jiang, J.; Chan, Y.S.; Loh, Y.H.; Cai, J.; Tong, G.Q.; Lim, C.A.; Robson, P.; Zhong, S.; Ng, H.H. A core Klf circuitry regulates self-renewal of embryonic stem cells. Nat. Cell Biol. 2008, 10, 353-360. [CrossRef] [PubMed]

233. Tetreault, M.P.; Yang, Y.; Katz, J.P. Krüppel-like factors in cancer. Nat. Rev. Cancer 2013, 13, 701-713. [CrossRef] [PubMed]

234. Wang, C.; Li, L.; Duan, Q.; Wang, Q.; Chen, J. Krüppel-like factor 2 suppresses human gastric tumorigenesis through inhibiting PTEN/AKT signaling. Oncotarget 2017, 8, 100358-100370. [CrossRef]

235. Guo, X.; Deng, L.; Deng, K.; Wang, H.; Shan, T.; Zhou, H.; Liang, Z.; Xia, J.; Li, C. Pseudogene PTENP1 Suppresses Gastric Cancer Progression by Modulating PTEN. Anti Cancer Agents Med. Chem. 2016, 16, 456-464. [CrossRef]

236. Kim, S.J.; Lee, H.W.; Baek, J.H.; Cho, Y.H.; Kang, H.G.; Jeong, J.S.; Song, J.; Park, H.S.; Chun, K.H. Activation of nuclear PTEN by inhibition of Notch signaling induces G2/M cell cycle arrest in gastric cancer. Oncogene 2016, 35, 251-260. [CrossRef]

237. Ma, X.M.; Liu, Y.; Guo, J.W.; Liu, J.H.; Zuo, L.F. Relation of overexpression of S phase kinase-associated protein 2 with reduced expression of p27 and PTEN in human gastric carcinoma. World J. Gastroenterol. 2005, 11, 6716-6721. [CrossRef] 
238. Guo, S.L.; Ye, H.; Teng, Y.; Wang, Y.L.; Yang, G.; Li, X.B.; Zhang, C.; Yang, X.; Yang, Z.Z.; Yang, X. Akt-p53-miR-365-cyclin D1/cdc25A axis contributes to gastric tumorigenesis induced by PTEN deficiency. Nat. Commun. 2013, 4, 2544. [CrossRef]

239. Shanmugam, M.K.; Manu, K.A.; Ong, T.H.; Ramachandran, L.; Surana, R.; Bist, P.; Lim, L.H.; Kumar, A.P.; Hui, K.M.; Sethi, G. Inhibition of CXCR4/CXCL12 signaling axis by ursolic acid leads to suppression of metastasis in transgenic adenocarcinoma of mouse prostate model. Int. J. Cancer 2011, 129, 1552-1563. [CrossRef]

240. Shin, E.M.; Hay, H.S.; Lee, M.H.; Goh, J.N.; Tan, T.Z.; Sen, Y.P.; Lim, S.W.; Yousef, E.M.; Ong, H.T.; Thike, A.A.; et al. DEAD-box helicase DP103 defines metastatic potential of human breast cancers. J. Clin. Investig. 2014, 124, 3807-3824. [CrossRef]

241. Zhong, X.; Liu, D.; Jiang, Z.; Li, C.; Chen, L.; Xia, Y.; Liu, D.; Yao, Q.; Wang, D. Chrysin Induced Cell Apoptosis and Inhibited Invasion Through Regulation of TET1 Expression in Gastric Cancer Cells. Oncotargets Ther. 2020, 13, 3277-3287. [CrossRef] [PubMed]

242. Su, P.H.; Hsu, Y.W.; Huang, R.L.; Chen, L.Y.; Chao, T.K.; Liao, C.C.; Chen, C.W.; Wu, T.I.; Mao, S.P.; Balch, C.; et al. TET1 promotes $5 \mathrm{hmC}$-dependent stemness, and inhibits a $5 \mathrm{hmC}$-independent epithelial-mesenchymal transition, in cervical precancerous lesions. Cancer Lett. 2019, 450, 53-62. [CrossRef] [PubMed]

243. Collignon, E.; Canale, A.; Al Wardi, C.; Bizet, M.; Calonne, E.; Dedeurwaerder, S.; Garaud, S.; Naveaux, C.; Barham, W.; Wilson, A.; et al. Immunity drives TET1 regulation in cancer through NF-кB. Sci. Adv. 2018, 4, eaap7309. [CrossRef] [PubMed]

244. Xiang, Z.; Xu, C.; Wu, G.; Liu, B.; Wu, D. CircRNA-UCK2 Increased TET1 Inhibits Proliferation and Invasion of Prostate Cancer Cells Via Sponge MiRNA-767-5p. Open Med. 2019, 14, 833-842. [CrossRef] [PubMed]

245. Duan, H.; Yan, Z.; Chen, W.; Wu, Y.; Han, J.; Guo, H.; Qiao, J. TET1 inhibits EMT of ovarian cancer cells through activating Wnt/ $\beta$-catenin signaling inhibitors DKK1 and SFRP2. Gynecol. Oncol. 2017, 147, $408-417$. [CrossRef]

246. Pei, Y.F.; Tao, R.; Li, J.F.; Su, L.P.; Yu, B.Q.; Wu, X.Y.; Yan, M.; Gu, Q.L.; Zhu, Z.G.; Liu, B.Y. TET1 inhibits gastric cancer growth and metastasis by PTEN demethylation and re-expression. Oncotarget 2016, 7, 31322-31335. [CrossRef]

247. Gan, L.; Xu, M.; Hua, R.; Tan, C.; Zhang, J.; Gong, Y.; Wu, Z.; Weng, W.; Sheng, W.; Guo, W. The polycomb group protein $\mathrm{EZH} 2$ induces epithelial-mesenchymal transition and pluripotent phenotype of gastric cancer cells by binding to PTEN promoter. J. Hematol. Oncol. 2018, 11, 9. [CrossRef]

248. Jackstadt, R.; van Hooff, S.R.; Leach, J.D.; Cortes-Lavaud, X.; Lohuis, J.O.; Ridgway, R.A.; Wouters, V.M.; Roper, J.; Kendall, T.J.; Roxburgh, C.S.; et al. Epithelial NOTCH Signaling Rewires the Tumor Microenvironment of Colorectal Cancer to Drive Poor-Prognosis Subtypes and Metastasis. Cancer Cell 2019, 36, 319-336.e317. [CrossRef]

249. Zhang, Y.; Xie, Z.Y.; Guo, X.T.; Xiao, X.H.; Xiong, L.X. Notch and breast cancer metastasis: Current knowledge, new sights and targeted therapy. Oncol. Lett. 2019, 18, 2743-2755. [CrossRef]

250. Guo, J.; Li, P.; Liu, X.; Li, Y. NOTCH signaling pathway and non-coding RNAs in cancer. Pathol. Res. Pract. 2019, 215, 152620. [CrossRef]

251. Kim, H.; Yu, Y.; Choi, S.; Lee, H.; Yu, J.; Lee, J.H.; Kim, W.Y. Evodiamine Eliminates Colon Cancer Stem Cells via Suppressing Notch and Wnt Signaling. Molecular 2019, 24, 4520. [CrossRef] [PubMed]

252. Baron, M.; Aslam, H.; Flasza, M.; Fostier, M.; Higgs, J.E.; Mazaleyrat, S.L.; Wilkin, M.B. Multiple levels of Notch signal regulation (review). Mol. Membr. Biol. 2002, 19, 27-38. [CrossRef] [PubMed]

253. Grishina, I.B. Mini-review: Does Notch promote or suppress cancer? New findings and old controversies. Am. J. Clin. Exp. Urol. 2015, 3, 24-27.

254. Yap, L.F.; Lee, D.; Khairuddin, A.; Pairan, M.F.; Puspita, B.; Siar, C.H.; Paterson, I.C. The opposing roles of NOTCH signalling in head and neck cancer: A mini review. Oral Dis. 2015, 21, 850-857. [CrossRef] [PubMed]

255. Zhang, X.S.; Hu, Y.H.; Gao, H.Y.; Lan, X.W.; Xue, Y.W. Downregulation of Notch1 inhibits the invasion and metastasis of human gastric cancer cells SGC7901 and MKN74 in vitro through PTEN activation and dephosphorylation of Akt and FAK. Mol. Med. Rep. 2017, 16, 2318-2324. [CrossRef] 
256. Xiong, J.; Li, Z.; Zhang, Y.; Li, D.; Zhang, G.; Luo, X.; Jie, Z.; Liu, Y.; Cao, Y.; Le, Z.; et al. PRL-3 promotes the peritoneal metastasis of gastric cancer through the PI3K/Akt signaling pathway by regulating PTEN. Oncol. Rep. 2016, 36, 1819-1828. [CrossRef]

257. Wendel, H.G.; De Stanchina, E.; Fridman, J.S.; Malina, A.; Ray, S.; Kogan, S.; Cordon-Cardo, C.; Pelletier, J.; Lowe, S.W. Survival signalling by Akt and eIF4E in oncogenesis and cancer therapy. Nature 2004, 428, 332-337. [CrossRef]

258. West, K.A.; Castillo, S.S.; Dennis, P.A. Activation of the PI3K/Akt pathway and chemotherapeutic resistance. Drug Resist. Updates 2002, 5, 234-248. [CrossRef]

259. Knuefermann, C.; Lu, Y.; Liu, B.; Jin, W.; Liang, K.; Wu, L.; Schmidt, M.; Mills, G.B.; Mendelsohn, J.; Fan, Z. HER2/PI-3K/Akt activation leads to a multidrug resistance in human breast adenocarcinoma cells. Oncogene 2003, 22, 3205-3212. [CrossRef]

260. Oki, E.; Baba, H.; Tokunaga, E.; Nakamura, T.; Ueda, N.; Futatsugi, M.; Mashino, K.; Yamamoto, M.; Ikebe, M.; Kakeji, Y.; et al. Akt phosphorylation associates with LOH of PTEN and leads to chemoresistance for gastric cancer. Int. J. Cancer 2005, 117, 376-380. [CrossRef]

261. Xu, W.; Yang, Z.; Xie, C.; Zhu, Y.; Shu, X.; Zhang, Z.; Li, N.; Chai, N.; Zhang, S.; Wu, K.; et al. PTEN lipid phosphatase inactivation links the hippo and PI3K/Akt pathways to induce gastric tumorigenesis. J. Exp. Clin. Cancer Res. 2018, 37, 198. [CrossRef] [PubMed]

262. Mina, S.; Bohn, B.A.; Simon, R.; Krohn, A.; Reeh, M.; Arnold, D.; Bokemeyer, C.; Sauter, G.; Izbicki, J.R.; Marx, A.; et al. PTEN deletion is rare but often homogeneous in gastric cancer. J. Clin. Pathol. 2012, 65, 693-698. [CrossRef] [PubMed]

263. Zhao, C.L.; Han, S.N.; Wang, Z.J.; Wang, S.H.; Zhao, G.Q.; Zhang, X.F.; Wang, J.X. Concomitant modulation of PTEN and Livin in gastric cancer treatment. Int. J. Mol. Med. 2018, 41, 2901-2908. [CrossRef]

264. Zhang, L.L.; Liu, J.; Lei, S.; Zhang, J.; Zhou, W.; Yu, H.G. PTEN inhibits the invasion and metastasis of gastric cancer via downregulation of FAK expression. Cell. Signal. 2014, 26, 1011-1020. [CrossRef] [PubMed]

265. Zhu, X.; Qin, X.; Fei, M.; Hou, W.; Greshock, J.; Bachman, K.E.; Kang, J.; Qin, C.Y. Loss and reduced expression of PTEN correlate with advanced-stage gastric carcinoma. Exp. Ther. Med. 2013, 5, 57-64. [CrossRef] [PubMed]

266. Hang, Y.; Zheng, Y.C.; Cao, Y.; Li, Q.S.; Sui, Y.J. Suppression of gastric cancer growth by adenovirus-mediated transfer of the PTEN gene. World J. Gastroenterol. 2005, 11, 2224-2229. [CrossRef]

267. Canbay, E.; Kahraman, O.T.; Bugra, D.; Caykara, B.; Seyhan, M.F.; Bulut, T.; Yamaner, S.; Ozturk, O. Increased gastric cancer risk with PTEN IVS4 polymorphism in a Turkish population. Genet. Test. Mol. Biomark. 2013, 17, 249-253. [CrossRef]

(C) 2020 by the authors. Licensee MDPI, Basel, Switzerland. This article is an open access article distributed under the terms and conditions of the Creative Commons Attribution (CC BY) license (http://creativecommons.org/licenses/by/4.0/). 